\title{
ELEKTRİK ENERJİSİ NAKİL HATLARININ YOL AÇTIĞI ZARARDAN SORUMLULUK*
}

\author{
Responsibility For Damages Caused By Electricity Power Transmission Lines \\ Dr. Öğr. Üyesi Bahar ÖCAL APAYDIN**
}

\begin{abstract}
ÖZ
Elektrik enerjisi doğada bulunduğu biçimi ile kullanılan birincil enerji kaynaklarının bir süreçten geçirilmesi sonucu üretilen ikincil enerji kaynağıdır. Elektrik enerjisi, güç üretiminin yanı sıra ısı ve ışık kaynağı olarak da kullanıldığından hayati bir öneme sahiptir. Kullanım alanı oldukça geniş olan elektrik enerjisi depolanamamaktadır. O nedenle üretimi kadar elektrik enerjisinin aktarımı ve taşınması da büyük önem arz eder. Elektrik enerjisinin aktarımı ve taşınması, iletken elektrik telleri üzerinden gerçekleştirilmektedir. Elektrik enerjisinin taşınması ve aktarılması için kullanılan iletken teller, elektrik enerjisi nakil hatlarını oluşturur. Bu iletken teller üzerinden ise sürekli elektrik geçmekte ve belirli bir yaklaşma mesafesindeki insan yahut iletken bir cisim akıma kapılabilmektedir. Bu suretle elektrik enerjisi nakil hatları bazen ölümcül bazen ağır zararlara neden olabilmektedir. Türk hukukunda elektrik enerjisi nakil hatlarının neden olduğu zarardan sorumluluğun bir kusursuz sorumluluk olduğu öğretide ve uygulamada kabul edilmektedir. Buna karşılık sorumluluğun türü bakımından uygulama birliği bulunmamaktadır. Bunun nedeni, bazı hukuk düzenlerinin aksine Türk hukukunda elektrik enerjisi nakil hatlarının neden olduğu zarardan sorumluluğunun özel bir kanunla düzenlenmemiş olmasıdır. Dolayısıyla elektrik enerjisi nakil hatlarının yol açtığı zarardan sorumluluk Türk Borçlar Kanunu'nun genel hükümlerine göre belirlenmektedir. Bu çalışmanın amacı öncelikle, karşılaştırmalı hukukta elektrik enerjisi nakil hatlarının yol açtığı zarardan sorumluluğu incelemek, ardından Türk hukukunda öğreti ve Yargıtay kararlarının değerlendirerek, bu sorumluluğu ele almaktır. Böylece elektrik enerjisi nakil hatlarının neden olduğu zarardan sorumluluğun türü belirlenmeye çalışılacaktır.
\end{abstract}

ANAHTAR KELIMELER: Elektrik enerjisi nakil hattı, Elektrik enerjisi nakil faaliyeti, Tehlike Sorumluluğu, Mecra, Yapı Malikinin Sorumluluğu

\section{ABSTRACT}

Electrical energy is the secondary energy source produced as a result of a process of the primary energy sources used as it is in nature. Electrical energy is of vital importance as it is used as a source of heat and light as well as power generation. Electrical energy, which has a wide usage area, cannot be stored. Therefore, the transfer and transport of electrical energy is as important as its production. Transmission and transport of electrical energy is carried out via conductive electrical wires. Conductive wires used for transporting and transferring electrical energy form electrical power transmission lines. Due to a continuous electricity is passed over these conductive wires and a human or a conductive object with a certain distance can be caught in the current. Therefore, electric power transmission lines can cause sometimes fatal and severe damages. In the Turkish legal system, the responsibility for the damage caused by electric power transmission lines is considered as a responsibility that is not based on fault. However, there is no unity of practice in terms of determination of the type of responsibility. This is due to the fact that, unlike some other legal systems, the Turkish legal system does not contain a law regarding the liability for damages caused by electric power lines. Therefore, the type of responsibility is determined according to the general provisions of the Turkish Code of Obligations. The aim of this study is to examine first the responsibility of the damages caused by electric power transmission lines in different legal systems, and then to address the Turkish legal system and analyse this responsibility by evaluating the doctrine and the decisions of Court of Cassation. Thus, the type of liability will be identified for the damage caused by the electric power transmission lines.

KEY WORDS: Electricity Power Transmission Line, Electricity Power Transmission Activity, Strict Liability For Dangerous Activity, Conduits, Liability Of Property Owners.

\footnotetext{
* Yayın Kuruluna Ulaştığı Tarih: 09.07.2019

Kabul Edildiği Tarih: 31.07.2019

DOI Numarası: $\underline{10.15337 / \text { suhfd.603710 }}$

** İnönü Üniversitesi Hukuk Fakültesi, Medeni Hukuk Anabilim Dalı

E-mail Adresi: bahar.apaydin@inonu.edu.tr

ORCID ID: 0000-0001-9106-8286
}

Makaleye Atıf: Öcal Apaydın, Bahar: Elektrik Enerjisi Nakil Hatlarının Yol Açtığı Zarardan Sorumluluk, Selçuk Üniversitesi Hukuk Fakültesi Dergisi, C.27, S.2, 2019, s.307-344. 


\section{GiRiş}

Hem güç üretiminde hem de ısı ve ışık kaynağı olarak kullanılan elektrik, önemli bir enerji kaynağıdır. Elektrik enerjisi doğada bulunduğu biçimi ile kullanılan ve birincil enerji kaynağı olarak nitelendirilen bir enerji kaynağı değildir. Ancak elektrik enerjisi, doğal kaynakların bir süreçten geçirilmesi sonucu üretilen ikincil bir enerji kaynağıdır.

Elektrik enerjisi, kullanım alanının genişliği nedeniyle enerji ihtiyacının karşılanması bakımından önemli bir yere sahiptir. Bu kadar hayati bir enerji kaynağı olan elektrik enerjisi depolanamamaktadır. O nedenle üretimi kadar elektrik enerjisinin aktarımı ve taşınması da büyük önem arz eder. Elektrik enerjisi, iletken elektrik tellerinden aktarılmakta ve taşınmaktadır. 6446 Sayılı Elektrik Piyasası Kanunu ${ }^{1}$ (EPK) yüksek gerilim hatlarından elektrik enerjisinin taşınmasını iletim, orta ve alçak gerilim hatlarından aktarılmasını dağıtım olarak nitelemektedir. Elektrik Kuvvetli Akım Tesisleri Yönetmeliği² (EKAT Yön.) uyarınca "yüksek gerilim; etkin değeri 1000 voltun üstünde olan fazlar arası gerilimi" ifade eder. İletim bakımından gerilim sınırı ise Enerji Piyasası Kanunu'nda "36kV (36000Volt)" olarak ifade edilmektedir. Bu gerilim sınırının altında olan hatlardan elektriğin nakli dağıtım olarak ifade edilmektedir.

Türk hukukunda enerji nakil hatlarının neden olduğu zarardan sorumluluğun kusura dayanmayan bir sorumluluk olduğu gerek öğretide gerekse uygulamada ittifakla kabul edilmektedir. Ne var ki, sorumluluğun türü bakımından benzer bir yaklaşım söz konusu değildir. Bunun nedeni, bazı hukuk düzenlerinin aksine Türk hukukunda elektrik enerjisi nakil hatlarının neden olduğu zarardan sorumluluğun özel bir kanunla düzenlenmemiş olmasıdır. 818 Sayılı Borçlar Kanunu (818 sayılı BK) döneminde elektrik enerjisi nakil hatlarının neden olduğu zarardan sorumluluk 818 sayılı BK m. 58 uyarınca yapı malikinin sorumluluğu kapsamında değerlendirilmekteydi. 6098 Sayılı Türk Borçlar Kanunu (TBK) m. 71 hükmü ile genel bir tehlike sorumluluğu ihdas edilmiştir. Bu suretle öğretide elektrik enerjisi nakil vasıtalarının neden olduğu zarardan sorumluluğun TBK m. 71 hükmü kapsamında tehlike sorumluluğu olarak nitelendirilmesi gerektiği ileri sürülmektedir. Buna karşılık Yargıtay kararlarında da bir uygulama birliği bulunmamaktadır. Yargıtay, elektrik enerjisi nakil hatlarının neden olduğu zarardan sorumluluğun kimi zaman TBK m. 69 hükmü uyarınca yapı malikinin sorumluluğu kapsamında değerlendirmekte ${ }^{3}$, kimi zaman hem TBK m. 69 hükmüne

$1 \quad$ R.G. Tarih: 30.03.2013, Sayı: 28603.

$2 \quad$ R.G. Tarih: 30.11 .2000 , Sayı: 24246.

3 Yarg. 3. HD T. 15.06.2015, 2014/18931 E.- 2015/11009K.; Yarg. 3. HD T. 31.05.2016, 2015/16137E.-2016/8587K.; Yarg. 3. HD, T. 19.04.2016, 2016/5938E.-2016/6068K.; Yarg. 3. HD T. 16.03.2016, 2015/7031E.- 2016/3998K.; Yarg. 3. HD T. 16.02.2016, 2016/135E.2016/1986K.; Yarg. 3. HD T. 26.09.2016, 2015/15388E.-2016/11182 K.; Yarg. 3. HD T. 
hem de TBK m. 71 hükmüne atıf yapmak suretiyle genel olarak objektif sorumluluk kapsamında değerlendirmekte ${ }^{4}$, kimi zaman da sorumluluğu TBK m. 71 hükmüne dayandırmaktadır ${ }^{5}$. Gerek sorumluluğun dayandığı esaslar, gerek sorumluluğun koşulları gerekse sorumlu kişilerin tespiti bakımından yapı malikinin sorumluluğu ile tehlike sorumluluğu farklılık göstermektedir. O nedenle elektrik enerjisi nakil vasıtalarının neden olduğu zarardan sorumluluğun türünün belirlenmesi sadece teorik bir çabadan ibaret olmamalı özellikle uygulamada bir birlik sağlanması amacına da yönelmelidir.

Bu çalışmada farklı hukuk düzenlerinden seçilen birkaç örnek üzerinden elektrik enerjisi nakil vasıtalarının neden olduğu zarardan sorumluluk incelenecek ve Türk hukukunda bu sorumluluğun nasıl ele alındığı özellikle Yargıtay kararları ile ortaya koyulacaktır. Bu suretle elektrik enerjisi nakil hatlarının neden olduğu zarardan sorumluluğun türünün belirlenmesi amaçlanmaktadır.

\section{Genel Olarak Elektrik Tesisleri ve Elektrik Enerjisi Nakil Hatları}

Elektrik, bir başka enerji kaynağının dönüştürülmesi sonucunda elde edilen ikincil bir enerji kaynağıdır ${ }^{6}$. Daha açık bir anlatımla elektrik enerjisi, su, rüzgâr, kömür gibi doğada bulunduğu biçimi ile kullanılan birincil enerji kaynaklarının üretim tesisinde, belirli bir süreçten geçirildikten sonra fiziki değişime uğraması sonucunda elde edilen ikincil nitelikte bir enerji kaynağıdır ${ }^{7}$. Elektrik enerjisi homojen bir yapıdadır ${ }^{8}$. Dolayısıyla hangi kaynaktan üretildiği bilinmeksizin şebekeye aktarılmaktadır ve şebekeden kullanılan elektriğin kaynağı tespit edilememektedir ${ }^{9}$.

Elektrik Piyasası Kanunu'nda üç ana faaliyet öngörülmüştür. Bunlar üretim, iletim ve dağıtım faaliyetleridir.

21.12.2015, 2015/1137E.-2015/20626K.; Yarg. 3. HD T. 12.4.2016, 2015/8685E.-2016/5628K. (www.lexpera.com.tr, erişim tarihi: 18.03.2019).

4 Yarg. 4 HD T.17.06.2017, 2016/6701E.-2017/17400K.; Yarg. 4 HD T.21.12.2015, 2015/1137E.2014/20626K. (www.lexpera.com.tr, erişim tarihi: 18.03.2019).

$5 \quad$ Yarg. 3 HD 03.11.2015, 2014/20465E.-2015/17103K.; Yarg. 4 HD T.17.06.2014, 2014/4403E.2014/9751K. (www.corpus.com.tr, erişim tarihi: 20.09.2018); Yarg. 3 HD T.17.06.2014, 2014/4430E.-2014/9752K. (www.lexpera.com.tr, erişim tarihi: 18.03.2019); Yarg. 3 HD 05.11.2014, 2014/6427E.-2014/14466K. (www.corpus.com.tr, erişim tarihi: 20.09.2018).

6 FILTHAUT, Werner: Haftpflichtgesetz, Kommentar zur Haftpflichtgesetz und zu den konkurrierenden Vorschriften anderer Haftungsgesetze, 9. Völlig neu bearbeitete Auflage 2015, C.H. Beck, München, N.8.

7 YAVUZ, Mustafa: Elektrik Piyasası Kanunu'nun Öngördüğü Hukuki Rejim ve Elektrik Tedarik Sözleşmeleri-Özellikle İkili Anlaşma-, İstanbul 2011, s. 16-17.

8 AYRANCI, Hasan: Enerji Sözleşmeleri, Ankara 2010, s. 46; YAVUZ, s. 19.

9 AYRANCI, s. 46; YAVUZ, s. 19. 
Üretimden kasıt, birincil enerji kaynaklarının elektrik üretim tesislerinde elektrik enerjisine dönüştürülmesidir (EPK m. 3/f.1-öö). Elektrik enerjisinin üretimi, doğalgaz gibi birincil enerji kaynaklarının veya nükleer enerji gibi farkı şekillerde bulunan enerjinin şekil değiştirerek elektrik enerjisine dönüşmesini ifade etmektedir ${ }^{10}$.

Elektrik enerjisini depolamak mümkün olmadığından üretildiği anda enerjinin kullanılması gerekmektedir ${ }^{11}$. Diğer bir deyişle, elektrik enerjisi üretildiği anda üretim tesisinden ayrılmaktadır ${ }^{12}$. O nedenle elektriğin üretimi kadar aktarılması ve taşınması da büyük önem arz etmektedir. Üretilen elektrik enerjisi, öncelikle üretim tesisinin $36 \mathrm{kV}$ üstü gerilim seviyesi ile bağlı olduğu iletim tesisine aktarılmakta ve bu tesislerden taşınmaktadır ${ }^{13}$. Dolayısıyla elektrik enerjisinin yüksek gerilim hatlarında taşınması hâlinde iletim söz konusu olmaktadır. Nitekim Elektrik Piyasası Kanunu'na göre iletim, "elektrik enerjisinin gerilim seviyesi 36kV'ın üzerindeki hatlar üzerinden naklidir" (EPK m.3/f.1-k). Bu kapsamda iletim tesisi, "36kV'ın üzerindeki gerilim seviyesinden bağı olduğu üretim veya tüketim tesisi şalt sahasından sonraki nihayet direğinden itibaren iletim şalt sahalarının orta gerilim fiderleri de dâhil olmak üzere dağıtım tesislerinin bağlantı noktalarına kadar olan tesislerini" ifade etmektedir (EPK m.3/f.1n). Elektrik Kuvvetli Akım Tesisleri Yönetmeliği m.4/f.1a-5 uyarınca yüksek gerilim, etkin değeri 1000 voltun üstünde olan fazlar arası gerilimi ifade eder. Illetim bakımından gerilim sınırı ise EPK m. 3/f. 1-k hükmünde 36kV (36.000 volt) olarak belirlenmiştir.

Belirtmek gerekir ki, iletim hatlarındaki yüksek voltajlı elektrik enerjisi, doğrudan kullanıma uygun olmadığından transformatör merkezlerinde dağııım için uygun voltaj seviyesine indirilmektedir ${ }^{14}$. Bu sayede elektrik enerjisi tüketicinin kullanımına uygun hâle getirilmekte ve alçak gerilim seviyesine düşürülen elektrik enerjisi tüketicinin kullanımına sunulmaktadı ${ }^{15}$. Elektrik enerjisinin ortak ve alçak gerilim seviyesinde iletim tesisinden tüketiciye aktarılması bakımından taşınması işlemi ise dağııım olarak nitelendirilmektedir ${ }^{16}$. Nitekim Elektrik Piyasası Kanunu'na göre dağıtım, "elektrik enerjisinin $36 \mathrm{kV}$ ve altındaki hatlar üzerindeki naklini" ifade eder (EPK m.

10 Üretim süreci, kimyasal yollardan yanma yahut nükleer reaksiyon şeklinde olabileceği gibi rüzgâr veya su gücünde olduğu gibi kinetik enerjinin form değiştirmesi şeklinde gerçekleşir (YAVUZ, s. 21).

11 AYRANCI, s. 45; YAVUZ, s. 18.

12 YAVUZ, s. 18-19.

13 Üretilen elektrik enerjisi, transformatörler aracılığıyla iletim hatlarına aktarılmaktadır (YAVUZ, s. 17).

14 YAVUZ, s. 18.

15 YAVUZ, s. 18.

16 YAVUZ, s. 24. 
3/f.1-ç). Dağıtım tesisi ise "iletim tesislerinin ve dağıtım gerilim seviyesinden bağlı üretim ve tüketim tesislerine ait şalt sahalarının bittiği noktadan sonraki nihayet direğinden, alçak gerilim seviyesinden bağlı tüketicilerin yapı bina giriş noktalarına kadar, bina giriş ve sayaç arası hariç, elektrik dağıtımı için teçhiz edilmiş tesis ve teçhizat ile dağıtım şirketince teçhiz edilen ya da devralınan sayaçlardan" oluşur (EPK m. 3/f.1-f).

\section{Karşılaştırmalı Hukukta Elektrik Enerjisi Nakil Hatlarının Yol Açtığı Zarardan Sorumluluk}

\section{A. İsviçre Hukuku Bakımından}

İsviçre hukukunda elektrik enerjisi nakil hatlarının yol açtı̆̆ı zarardan sorumluluk özel bir kanunla düzenleme altına alınmıştır. İsviçre Kuvvetli ve Zayıf Akım Elektrik Tesislerine Iliş̧kin Federal Kanun ${ }^{17}$ (EleG) m. 27 hükmü uyarınca, özel ya da kamu mülkiyetinde olması arasında ayrım yapılmaksızın, kuvvetli akım ya da zayı akım tesisinin işletilmesi sırasında bir kişinin ölmesi yahut yaralanması hâlinde, tesisin sahibi meydana gelen zarardan sorumludur. Bir şeyin zarara uğraması hâlinde de aynı şekilde sorumluluk söz konusu olur (EleG m. 27/f.2). Ne var ki, işletme faaliyetinin durması esnasında zarar görenin uğradığı zarar bu kapsamda tazmin edilemez (EleG m. 27/f.2 ${ }^{18}$. Dolayısıyla EleG m. 27 hükmü kapsamında, elektrik tesisinin faaliyeti esnasında meydana gelen zarardan sorumluluk kast edilmektedir ${ }^{19}$.

EleG m. 27 hükmünde elektriğin üretimi, aktarılması ve taşınması bakımından elektrik tesisi sahibinin sorumluluğu düzenlenmiştir ${ }^{20}$. Bu kapsamda özel bir tehlike

17 Kanunun Fransızcası « Loi fédérale concernant les installations électriques à faible et à fort courant»; italyancası "Legge federale concernente gli impianti elettrici a corrente forte e a corrente debole»; Almancası "Bundesgesetz betreffend die elektrischen Schwach-und Starkstromanlagen» şeklindedir. 24 Haziran 1902 tarihli bu kanunun, İsviçre'nin en eski özel sorumluluk rejimi öngören kanunu olduğu ifade edilmektedir. O nedenle değişiklik önerileri ileri sürülmektedir (OFTINGER/STARK, § 28, N. 23; FELLMANN, Walter: Schweizerisches Haftpflichtrecht Band I bis III - eine Bilanz zum gesetzgeberischen Handlungsbedarf, (Herausgeber: FELLMANN, Walter/ WEBER, Stephan), Haftpflichtprozess HAVE, Schulthess Juristische Medien AG 2016, s. 184-185.

18 Bu nedenle kanunda değişiklik yapılması gerektiği ve elektrik enerjisi tesisinin faaliyeti nedeniyle doğan bu zarar kaleminin de tehlike sorumluluğu kapsamında tesis sahibi tarafından tazmin edilmesinin gerektiği yönünde bkz. FELLMANN, HAVE, s. 184-185.

19 KELLER, Alfred: Haftpflicht im Privatrecht, Band I, Sechste, vollständig überarbeitete und ergänzte Auflage, Stämpfli Verlag AG 2002, s. 233; ÇEKIN, Mesut Serdar: 6098 Sayılı Türk Borçlar Kanunu Madde 71 Çerçevesinde Tehlike Sorumluluğu, ìstanbul 2016, s. 233; DESCHENAUX Henri/TERCIER, Pierre: Sorumluluk Hukuku, (Çev. ÖZDEMIR, Salim), Ankara, 1983, s. 146.

20 KRATZ/LUDIN, KRATZ, Brigitta/ LUDIN, Martin: Haftpflichtkommentar, Kommentar zu den schweizerischen Haftpflichtbestimmungen, (Herausgeber: FISCHER, Willi / LUTERBACHER, Thierry), Dike Verlag AG, 2016, EleG Art. 27, N. 3; OFTINGER / STARK, § 28, N. 5, s. 118. 
arz ettiğinden, elektrik tesisinin faaliyetinden doğan sorumluluk özel bir kanunla düzenlenmiştir ${ }^{21}$. Böylece enerji tedarikinin sosyal ve ekonomik menfaatler bakımından önemi ile elektrik enerjisi tesislerinden kaynaklanan tehlike dengelenmektedir ${ }^{22}$.

EleG m. 27 hükmünde ifadesini bulan kusursuz sorumluluk, tehlikeli faaliyet esasına dayanmaktadır ${ }^{23}$. Diğer bir deyişle, bu sorumluluğun esası elektrik enerjisine ilişkin faaliyetin karakteristik tehlike arz eden bir faaliyet olmasıdır ${ }^{24}$. Bu suretle elektrik enerjisi tesisinin işletilmesinden tesis sahibinin sorumlu olması bakımından, tesisin işletilmesiyle birlikte karakteristik tehlikenin doğmuş olması yeterlidir ${ }^{25}$. Tesis sahibi, elektrik enerjisi tesisinin neden olduğu kişiye verilen zararlardan ve şeye verilen zararlardan sorumludur (EleG m. 27/f.1 ve 2). Böylece elektrik tesisi sahibinin, tehlikenin neden olduğu ekonomik riske her zaman kendisinin katlanması amaçlanmakta$\mathrm{d} \mathrm{r}^{26}$. Zira elektrik tesisi işletmek suretiyle ekonomik menfaat sağlayan da yine tesisin sahibidir ${ }^{27}$. Tesis sahibinin özel hukuk yahut kamu hukuku kişisi olması arasında ayrım gözetilmez ${ }^{28}$.

Kuvvetli akım yahut zayıf akım tesisinin işletilmesi nedeniyle zararın ortaya çıkması hâlinde EleG m. 27 hükmü uyarınca tesis sahibinin kusursuz sorumluluğu söz konusu olur. Tesis ile enerjinin üretimi, iletimi, dönüştürülmesi ve kullanılması için gerekli teknik donanım kast edilmektedir ${ }^{29}$. Zayıf akım tesisi, normal olarak kişi ya da şeye tehlike yaratacak akıma sahip olmayan tesis olarak değerlendirilmektedir (EleG m. 2). Bu elektrik tesislerindeki gerilim, genellikle 50 voltun altındadır (Alçak Gerilim Tesisleri Hakkında Yönetmelik ${ }^{30}$ m. 1/f.3). Bu tesisler normal olarak tehlikeli kabul

21 KLETT, Barbara/MÜLLER, Dominique: Risikosteuerung im Umgang mit "Emerging Risk", Editörler: BÜTLER, Micheal/SCHINDLER, Benjamin/SPRECHER, Franziska/ SUTTER Patrick, Sicherheit \&Recht 1/2017- S. 49, s. 49-57, https://www.swisslex.ch/Doc/ShowDocView/8c249f5226b4-4e5f-b0d6-90b11f48504f?hitPos=2\&tryHighlight=True\&source=hitlist-search\&SP=12 | dhtpnn\#firstSearchTerm (erişim tarihi: 18.10.2018), s. 13.

22 KRATZ/LUDIN, EleG, Art. 27, N. 3.

23 KELLER, S. 233.

24 KRATZ/LUDIN, EleG, Art. 27, N. 4.

25 KRATZ/LUDIN, EleG, Art. 27, N. 4.

26 KRATZ/LUDIN, EleG, Art. 27, N. 4.

27 KRATZ/LUDIN, EleG, Art. 27, N. 4.

28 OFTINGER/STARK, § 28 N. 34, s. 125; DESCHENAUX/TERCIER, s. 145.

29 OFTINGER/STARK, § 28 N. 13, s. 121; KELLER, s. 235; KRATZ/LUDIN, EleG, Art. 27, N. 5.

30 Yönetmeliğin Fransızca ismi, "Ordonnance sur les installations électriques à basse tension»; Italyanca ismi, "Ordinanza concernente gli impianti elettrici a bassa tensione»; Almanca ismi ise «Verordnung über elektrische Niederspannungsinstallationen (Niederspannungs-Installationsverordnung, NIV)» şeklindedir. 
edilmediğinden kural olarak, kusursuz sorumluluk kapsamında değerlendirilmesi gerekmez ${ }^{31}$. Ne var ki, zayıf akım tesislerinin de yol açtığı zarardan sorumluluğun kusursuz sorumluluk esasına dayandııımasının sebebi, bu tesislere kuvvetli akımın karışmasının mümkün olmasıdır ${ }^{32}$. O nedenle EleG m.4/f.1 hükmü uyarınca kamu arazisinden veya demiryolu bölgelerinden geçen yahut kuvvetli akım tesisine yakın olan zayıf akım tesislerinin tümünün tehlike arz edebileceği kabul edilmektedir. Dolaysıyla kamu arazilerinden, demiryolu bölgelerinden geçmeyen yahut kuvvetli akımın karışma tehlikesi olmayan zayıf akım tesislerinin neden olduğu zararlardan sorumluluk, EleG m. 27 hükmünde düzenlenmiş olan kusursuz sorumluluğun dışında kalmaktadır ${ }^{33}$. Bu hâlde İsviçre Borçlar Kanunu'na göre zararın tazmini söz konusu olur. Belirtmek gerekir ki, her somut olaya göre değerlendirme yapılarak, sorumluluğun EleG m. 27 hükmü kapsamına girip girmediği tespit edilmelidir ${ }^{34}$. EleG m. 2/f.2 hükmünde ise ürettiği yahut kullandığı akımın insan veya eşya için tehlikeli olması hâlinde akım tesisi, kuvvetli akım tesisi olarak ifade edilmektedir. Söz konusu tesisler, 50 voltun üzerinde gerilime sahip olan ve EleG m. 27 uyarınca kusursuz sorumluluğun esas uygulama alanını teşkil eden tesislerdir ${ }^{35}$.

Mücbir sebep, üçüncü kişinin kusuru yahut zarar görenin kusuru zarara neden olmuşsa, illiyet bağı kesildiğinden tesis sahibi zararı tazmin yükümlülüğünden kurtul-

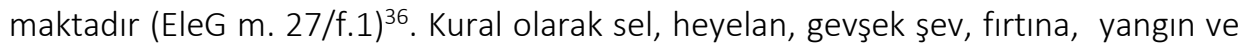
özellikle yıldırım mücbir sebep kapsamında değerlendirilemez ${ }^{37}$. İsviçre Federal Mahkemesi de bir kararında yangın felaketini mücbir sebep olarak kabul etmemiştir ${ }^{38}$. Yıldırım her ne kadar mücbir sebebin klasik örneklerinden biri olsa da yıldıımın farkı değerlendirildiği ve her hâlde illiyet bağını kesen bir neden olarak değerlendirilmediği görülmektedir. Yıldııımın, elektrik tesisine düşmesi sebebiyle ani akım oluşması sonucu, yıldırımın mücbir sebep olarak değerlendirildiği ve illiyet bağını kestiği kabul edilmektedir ${ }^{39}$.

\footnotetext{
31 KELLER, s. 234; OFTINGER/STARK, § 28, N. 11, s. 120.

32 KELLER, s. 234; KRATZ/LUDIN, EleG, Art. 27, N. 6; OFTINGER/STARK, § 28, N. 11, s. 120.

33 KELLER, s. 234; OFTINGER/STARK, § 28, N. 30, s. 124; KRATZ/LUDIN, EleG, Art. 27, N. 7.

34 KRATZ/LUDIN, EleG, Art. 27, N. 7.

35 KELLER, s. 234; KRATZ/LUDIN, EleG, Art. 27, N. 8.

36 KELLER, s. 233; KLETT/MÜLLER, s. 13; KRATZ/LUDIN, EleG, Art. 27, N. 4.

37 OFTINGER/STARK, § 28, N. 137, s. 156.

38 BGE 63 ॥ 114.

39 OFTINGER/STARK, § 28, N. 138, s. 156; KELLER, s. 239.
} 


\section{B. Alman Hukuku Bakımından}

Alman hukukunda elektrik nakil vasıtalarının neden olduğu zarardan sorumluluk, Alman Sorumluluk Kanunu ${ }^{40}$ (HPflG) § 2'de düzenlenmiştir ${ }^{41}$. HPflG § 2 (1) 1 hükmü uyarınca elektrik sağlamaya yarayan tesisler veya elektriği iletmeye yarayan tesisler nedeniyle birinin ölmesi veya sağlık ya da vücut bütünlüğünün zedelenmesi ya da bir eşyanın zarar görmesi hâlinde söz konusu tesislerin sahipleri, doğan zararları tazmin etmekle yükümlüdürler ${ }^{42}$. HPfIG $\S 2$ hükmünde, tehlikeli tesislerin neden olduğu zararı giderme yükümlülüğü, kusursuz sorumluluk şeklinde düzenlenmiştir ${ }^{43}$. Bu kapsamda sorumluluğa neden olan tesisler, tipik olarak tehlikeye neden olmalıdı ${ }^{44}$. Diğer bir deyişle, Alman kanun koyucusu elektrik enerjisi naklini tehlikeli kabul etmekte ve sorumluluğu ona göre tayin etmektedir. Bu hâlde dar anlamda tehlike sorumluluğunun söz konusu olduğu kabul edilmektedir ${ }^{45}$. O nedenle sorumluluğun kapsamı, sorumluluk sebebine tabi olmaktadır ${ }^{46}$. Zararı gidermekle yükümlü olan, tesisin tehlikesi nedeniyle zarara katlanması gereken tesis sahibidir ${ }^{47}$.

Elektrik tesisinden bahsedebilmek için tesisin belirli bir bağımsızlığının olması gerekir $^{48}$. Ne var ki, bina yahut ev bağlantısı gibi bir başka sisteme bağlı olması tesisin bağımsızlığını kaybettiği anlamına gelmez ${ }^{49}$. Ayrıca tesisin, yerin altında ya da üstünde olması da önem arz etmez ${ }^{50}$. Örneğin, sorumluluk bakımından elektriğin yerin üzerindeki tesislerden yahut yeraltı bağlantı kablolarından aktarıması arasında fark gözetilmez ${ }^{51}$. Diğer yandan tesisin uzun süreli ya da geçici olması da sorumluluk bakımından

40 Kanunun orijinal adı, Haftpflichtgesetz'dir.

41 Söz konusu düzenlemede zarara neden olan enerji tesisi yalnızca elektrik enerjisi nakil hatları ile sınırlı olmayıp, gaz veya diğer sıvı kaynakları da içermektedir.

42 WELLER, Matthias: Haftungsrecht Gefahrstoffe: die zivilrechtliche Haftung für Schäden aus gefährlichen chemischen Reaktionen, Ecomed-Storck GmbH, 2007, s. 61.

43 FILTHAUT, HPfIG § 2, N.5.

44 Örneğin Federal Alman Yüksek Mahkemesi, düşen yağmur borularının neden olduğu zarardan sorumluluğu § $2 \mathrm{HPflG}$ hükmü kapsamında görmemiştir. Zira söz konusu tesis, tipik tehlikeli bir tesis değildir (BGH NJW 1960, s. 1345 = VersR 1960, s. 242; FILTHAUT, HPfIG § 2, N. 6).

45 ÇEKIN, s. 78.

46 ÇEKIN, s. 78.

47 GÜNTHER, Dirk-Carsten: Der Regreß des Sachversicherers, Kalrsruhe 2008, s. 189.

48 FILTHAUT, HPFIG § 2, N.3.

49 FILTHAUT, HPFIG § 2, N.3.

50 FILTHAUT, HPfIG § 2, N.5; GÜNTHER, s. 189.

51 FILTHAUT, HPfIG § 2, N.5. 
farklı değerlendirilemez ${ }^{52}$. Örneğin, inşaat alanında yahut fuar alanında geçici bir süre için kullanılan elektrik hattı bakımından da aynı sorumluluk rejimi benimsenmiştir ${ }^{53}$.

HPfIG § 2 (1) 1 uyarınca sorumluluğun söz konusu olabilmesi için, tesisin elektrik enerjisi sağlama yahut işletme amacına hizmet etmesi gerekir ${ }^{54}$. HPfIG § 2 (1) 1 hükmü, doğrudan enerji üreten tesislerin, örneğin rüzgâr tribününün, neden olduğu zarardan sorumluluğu kapsamaz ${ }^{55}$. Ayrıca tüketim amacıyla kullanılan araçlar da HPfIG § 2 (1) 1 hükmünün uygulama alanı dışındadır ${ }^{56}$.

HPfIG § 2 (1) 1 uyarınca sorumluluk, tesisin tamamlanması ve faaliyete başlaması hâlinde söz konusu olur ${ }^{57}$. Tesisin faaliyeti sona ermişse, artık HPfIG § 2 (1) 1 anlamında sorumluluk söz konusu olmaz ${ }^{58}$. Dolayısıyla elektrik tesisinin neden olduğu zarardan sorumluluk, ancak elektrik tesisi faaliyette iken meydana gelmişse HPflG § 2 (1) 1 hükmü uyarınca tayin edilir ${ }^{59}$. Örneğin, elektrik nakil tesisinin tamamlanması ve elektriğin nakledilmesi hâlinde bir zarar meydana gelmişse HPfIG § 2 (1) 1 anlamında sorumluluk söz konusu olur. Şayet tesis tamamlanmışsa ve fakat henüz faaliyete başlanmamışsa, diğer bir deyişle elektrik nakli başlamamışsa HPfIG § 2 (1) 1 hükmü uygulama alanı bulmaz. Bu hâlde koşulları varsa HPfIG § 2 (1) 2 hükmü uygulanabilir. Ne var ki, tesis faaliyete başladıktan sonra meydana gelen geçici kesintiler sorumluluğun tayini bakımından HPfIG § 2 (1) 1 hükmünün uygulanmasına engel olmaz ${ }^{60}$.

Zararın, elektrik enerjisi nakil hattının faaliyeti neticesinde meydana gelmesi gerekir ${ }^{61}$. Dolayısıyla elektrik tesisinin nakil faaliyeti ile zarar arasında bağlantı olmalı ve bu faaliyet zararın kesin olarak nedeni olmalıdır ${ }^{62}$. Zira Alman kanun koyucusu, bu

\footnotetext{
52 FILTHAUT, HPfIG § 2, N.5.

53 FILTHAUT, HPfIG § 2, N.5.

54 FILTHAUT, HPfIG § 2, N.9.

55 FILTHAUT, HPfIG § 2, N.15; Mahkemelerin de bu yönde verilmiş kararları bulunmaktadır, örnek için bkz. BGH VersR 1985, s. 641

56 Ne var ki, tesisin enerji sağlama yahut işletme amacıyla yahut tüketim amacıyla kullanılıp kullanılmadığının tespiti zorluk arz edebilir. Somut olaya göre değerlendirilmesi gerekir (bkz. FILTHAUT, HPFIG § 2, N.16-17).

57 FILTHAUT, HPfIG § 2, N.19; GÜNTHER, s. 189; Kararlardan bazıları için bkz. OLG Oldenburg MDR 1958, s. 843; OLG Jena OLG-NL 2002, s. 38.

58 FILTHAUT, HPfIG § 2, N. 20; GÜNTHER, s. 189; BGH NJW 2006, s. 225.

59 WELLER, s. 61.

60 FILTHAUT, HPfIG § 2, N.19.

61 FILTHAUT, HPfIG § 2, N.22.

62 FILTHAUT, HPfIG § 2, N. 21, 22.
} 
faaliyetlerin özellikle tehlike arz etmesi nedeniyle kusursuz sorumluluk rejimini benimsemiştir ${ }^{63}$. Kural olarak mücbir sebep, sorumluluğu ortadan kaldırmaktadır. Buna karşılık mücbir sebepten dolayı yere düşen hatların neden olduğu zarar bakımından sorumluluk devam etmektedir (HPfIG § $3(3)^{64}$.

HPfIG § 2 (1) 2 hükmünde ise tesis sahiplerinin sorumluluğunun, sağlanan yahut iletilen elektrikten bağımsız olarak, anılan tesisler nedeniyle ortaya çıkan zararlar bakımından da söz konusu olduğu düzenlenmiştir65. Ancak bu hâlde, söz konusu tesisler hukuka uygun bir hâlde ise tesislerin sahipleri sorumluluktan kurtulabilirler. Diğer bir deyişle, bu tesisler zararın meydana geldiği anda hukuka uygun bir hâlde değilse, tesisten çıkan yahut tesiste iletilen elektriğin etkisi olmaksızın meydana gelen zararlar için de sorumluluk devam etmektedir. HPflG § 2 (1) 3 hükmü uyarınca dönemin teknik gelişmelerine uygun hasarsız yapıların hukuka uygun olduğu kabul edilmektedir ${ }^{66}$.

\section{C. İtalyan Hukuku Bakımından}

Italyan hukukunda elektrik nakil vasıtalarının verdiği zarardan sorumluluğun dayanağı, İtalyan Medeni Kanunu (it.MK) m. 2050 hükmünde ifadesini bulan tehlike esasına dayanan genel düzenlemedir. Buna göre niteliği gereği yahut kullanılan araçların niteliği gereği tehlikeli bir faaliyet yürütürken bir başkasına zarar veren kişi, zararı engellemek için gerekli önlemlerin tümünü aldığını ispatlamadığı takdirde, meydana gelen zararı tazminle yükümlüdür. İtalyan kanun koyucusu, it.MK m. 2050 hükmünde kusur sorumluluğu ile kusursuz sorumluluk arasında bir tercih yapmayarak, tehlike esasına dayanan sorumluluğu düzenlemiştir ${ }^{67}$. Öğretide bu sorumluluğun bir kusursuz sorumluluk olduğu kabul edilmektedir ${ }^{68}$. Buna karşlık, uygulamada zarar veren aleyhine kanundan kaynaklanan bir kusur karinesi olduğundan hareketle hüküm kurulmaktadır 69 .

\footnotetext{
63 FILTHAUT, HPfIG § 2, N.22.

64 FILTHAUT, HPfIG § 2, N. 70.

65 WELLER, s. 61.

66 WELLER, S. 61.
}

67 SELLA, Mauro: Commentario al Codice Civile, a cura di CENDON Paulo, artt. 2043-2053, Giuffré Editore, 2008, Art. 2050, s. 807 [Cendon Comm.].

68 COMPORTI, Marco: II Codice Civile Commentario, Fatti illeciti: le responsabilità oggettive, Artt. 2049-2053, Giuffrè Editore, 2009, s. 156 ve 158; TRIMARCHI, Pietro: Istituzioni di Diritto Privato, Giuffré Editore 2011, s. 136; GALGANO, Francesco: Diritto Privato, CEDAM 2017, s. 391; SELLA, Mauro: Art. 2050, Cendon Comm., s. 807-809.

69 Bkz. Cass. civ. Sez. III, 10.02.2003, n. 1954; Cass. civ. Sez. III, 12.12.1988, n. 6739. Bu yaklaşımın ayrıntılı eleştirisi için bkz. COMPORTI, s. 156-158. Ayrıca öğretide, İt. MK m. 2050 hükmünde kusura ilişkin değil ve fakat sorumluluğa ilişkin bir karine bulunduğu ileri sürülmektedir (SELLA, 
İtalyan Medeni Kanunu m. 2050 hükmü kapsamındaki sorumluluk, tehlikeli faaliyet kavramı ile sıkı bir bağlantı içindedir ${ }^{70}$. Faaliyetin bir işletme faaliyeti olmasına gerek olmadığı ve fakat zarara sebep olan herhangi bir tehlikeli faaliyetin bulunmasının yeterli olduğu ifade edilmektedir ${ }^{71}$. Öğretide ve uygulamada bir faaliyetin tehlikeli faaliyet olarak nitelendirilebilmesi için faaliyetin asgari bir sürekliliğinin olması ve kullanılan araçların tehlike yaratma istidadının olması gerektiği ifade edilmiştir ${ }^{72}$. Buna göre bir seferlik tehlike arz eden faaliyetten sorumluluk bu kapsamda değerlendirile$\mathrm{mez}^{73}$. Öğretide ve uygulamada zararın, tehlikeli bir faaliyetin yerine getirilmesi esnasında doğması gerektiği vurgulanmaktadır ${ }^{74}$. Zarar verici olay gerçekleşmeden önce faaliyet sona erdiği takdirde, it. MK m. 2050 uyarınca sorumluluğun tayin edilmemesi gerektiği uygulamada kabul edilmiştir ${ }^{75}$. Ne var ki, tehlikeli faaliyetin zarar verici sonuçlarının, faaliyet sona erdikten sonra ortaya çıkması hâlinde de it. MK m. 2050 hükmü uygulanır ${ }^{76}$.

Faaliyetin tehlikeli olup olmadığı hususunda esasen tehlikelilik kavramının nitelendirilmesi önem arz etmektedir. İ. MK m. 2050 hükmünde düzenlenen tehlike sorumluluğu bakımından tehlikeli faaliyetin niteliği veya kullanılan araçların ne kadar tehlike yarattığı dikkate alınmalıdır ${ }^{77}$. Kullanılan araçların normalde tehlikeli olmaması ve fakat kullanan kişinin tedbirsiz yahut dikkatsiz davranışı nedeniyle tehlikeli hâle gelmesi bu kapsamda değerlendirilmemelidir ${ }^{78}$. Özel kanunla yahut kamu güvenliğine ilişkin kanunlarla tehlikeli olarak nitelendirilen faaliyetler bakımından faaliyetin tehli-

Art. 2050, Cendon Comm., s. 809). Hükmün kusura ilişkin ispat yükünün yerini değiştirdiği yönünde bkz. TRIMARCHI, s. 137. 
keliliği kabul edilmelidir; ancak böyle bir hukuki dayanağın olmadığı hâllerde, faaliyetin kendi niteliği yahut kullanılan araçların niteliği gereği belirgin ve ağır zarar verme potansiyeli dikkate alınmalıdır ${ }^{79}$.

Uygulamada farklı faaliyet türleri bakımından, faaliyetin nicelik itibariyle veya durağan olarak tehlikeli olması, diğer bir deyişle gerek büyüklüğü gerekse oluş itibariyle tipik olarak zarara sebep olma kıstası benimsenmiştir ${ }^{80}$. Buna göre tehlikeli faaliyeti nitelendirmek adına iki kıstas önem taşır. Birincisi, söz konusu faaliyetin genellikle neden olduğu zararın niceliği; ikincisi ise zarar tehlikesinin ağırlığıdır ${ }^{81}$. Bu doğrultuda gerek faaliyetin niteliği gerekse kullanılan araçların niteliği değerlendirilmelidir. Ayrıca tehlikelilik kavramının dinamik ve teknolojik gelişmeler nedeniyle değişken bir kavram olduğu ifade edilmiştir ${ }^{82}$. O nedenle uygulamada tipik tehlikeli faaliyet ve atipik tehlikeli faaliyet şeklinde bir ayrım yapılmaktadır. Özel bir kanunla veya kamu güvenliğine ilişkin kanunlarla tehlikeli olarak kabul edilen ya da faaliyetin kendi niteliği yahut kullanılan araçların niteliği gereği belirgin ve ağır zarar verme potansiyeli taşıyan ve somut olarak tehlikeli olan faaliyetler tipik tehlikeli faaliyet olarak kabul edilmektedir ${ }^{83}$. Buna karşılık tipik tehlike olarak kabul edilen hâllerin dışında kalan ve fakat içinde somut tehlike barındırması yahut kullanılan araçların somut tehlike içermesi hâlinde anılan faaliyetler atipik tehlikeli faaliyet olarak nitelendirilmektedir ${ }^{84}$.

İtalyan Medeni Kanunu m. 2050 hükmünde kurtuluş kanıtı getirmek suretiyle sorumluluktan kurtulma imkânı getirilmiştir ${ }^{85}$. Buna göre sorumlu kişinin, tehlikeyi önlemek için gerekli özenin gösterildiğinin ispat edilmesi suretiyle sorumluluktan kurtulması mümkündür.

Uygulamada yüksek gerilim hatlarında elektrik nakli, tehlike arz eden faaliyet olarak nitelendirilmektedir ${ }^{86}$. Bu kapsamda yüksek gerilim hattında elektrik nakli, teknik niteliği gereği tehlikeli bir faaliyet olarak kabul edilmektedir ${ }^{87}$. Bu faaliyet elektrik

\footnotetext{
79 Cass. Civ. Sez. III, 15.10.2005, n. 20334.

80 SELLA, Art. 2050, Cendon Comm., s. 814.

81 SELLA, Art. 2050, Cendon Comm., s. 815.

82 COMPORTI, s. 172 vd.; Tehlikeli olarak kabul edilen bir faaliyetin, teknik gelişmeler sonucunda faaliyetin daha güvenli hâle gelmesi mümkündür (SELLA, Art. 2050, Cendon Comm., s. 816).

83 Cass. civ. Sez. III, 20.05.2015, n. 10268; Cass. civ. Sez. III, 07.01.1982, n. 537; Cass. civ. Sez. III, 16.01.2013, n. 919. SELLA, Art. 2050, Cendon Comm., s. 816.

84 SELLA, Art. 2050, Cendon Comm., s. 817.

85 Kurtuluş kanıtı ile ilgili ayrıntılı inceleme için bkz. SELLA, Art. 2050, Cendon Comm., s. 829.

86 Cass. civ. Sez. III, 27.01.1982, n. 537.

87 Cass. civ. Sez. III, 27.01.1982, n. 537.
} 
enerjisinin üretimi ve tedarikini yürüten kamu hukuku kişisi tarafından yerine getirilmektedir. Dolayısıyla elektrik enerjisi nakil faaliyeti esnasında üçüncü kişinin uğradığı zarardan sorumlu kişi, söz konusu kamu kurumu olmaktadır. Bu kapsamda özel hukuk kişisi ile kamu hukuku kişisi arasında fark gözetilmemektedir ${ }^{88}$.

Elektrik enerjisi alçak gerilim tesislerinin neden olduğu zarardan sorumluluk ise dağıtım faaliyetinin şekline göre tehlikeli kabul edilmektedir ${ }^{89}$. Bir olayda İtalyan Yargıtay'ı, "elektrik enerjisi kurumunun, harici elektrik nakil hatlarının yapılması ve nakil faaliyetinin yürütülmesine ilişkin güvenlik tedbirlerini hukuken düzenlemiş olduğunu vurgulamış ve kazanın gerçekleştiği yerdeki havai nakil hattının, dikey zincir eğrisinin en yakın binadan en az 3,20 m uzaklıkta olması gerekirken, teras kenarından $2 \mathrm{~m}$. uzaklıkta olduğundan alçak gerilim tesisinden elektrik naklini" tehlikeli faaliyet olarak kabul etmiştir ${ }^{90}$.

\section{Türk Hukukunda Elektik Enerjisi Nakil Hatlarının Yol Açtığı Zarardan Sorumluluk}

\section{A. Genel Olarak}

Türk hukukunda elektrik enerjisi taşınması amacıyla kullanılan elektrik enerjisi nakil vasıtaları, akım tesisi kapsamında değerlendirilmektedir. Zira EKAT Yön. m. 4/a1 hükmünde "kuvvetli akım tesisi, insanlar, diğer canlılar ve eşyalar için yaklaşma, dokunma gibi bazı hâllerde tehlikeli olabilecek ve elektrik enerjisinin üretilmesini, iletilmesini, dağıtılmasını ve mekanik enerji, ışık ve kimyasal enerji gibi enerjilere dönüştürülerek kullanılmasını sağlayan tesisler" şeklinde tanımlanmıştır.

EKAT Yön. m. 5'de kuvvetli akım tesislerinin, cana ve mala herhangi bir zarar vermeyecek ve tehlike oluşturmayacak bir biçimde yapılması gerektiği hükme bağlanmıştır. Ancak bu hüküm, özel bir düzenleme niteliğinde ayrı bir sorumluluk ihdas edildiği anlamına gelmemektedir. Dolayısıyla Türk hukukunda elektrik akım tesislerinin yol açtığı zararın tazmini bakımından, özel bir kanunla sorumluluk rejimi öngörülmemiştir.

818 sayılı Borçlar Kanunu döneminde elektrik enerjisi nakil vasıtalarının neden olduğu zarardan sorumluluk 818 sayılı BK m. 58 hükmü uyarınca yapı malikinin sorumluluğuna dayandırılmaktaydı. Zira özel bir kanunda elektrik tesislerinin neden olduğu zarardan sorumluluğa ilişkin bir düzenleme bulunmadığı ve ayrıca 818 sayılı Borçlar Kanunu'nda tehlike sorumluluğuna ilişkin genel bir hüküm de yer almadığı

\footnotetext{
88 Cass. civ. Sez. III, 27.01.2009, n. 1966; SELLA, Art. 2050, Cendon Comm., s. 811.

89 SELLA, Art. 2050, Cendon Comm., s. 838.

$90 \quad$ Cass. civ. Sez. III, 29.10.1989, n. 2584.
} 
için, Yargıtay bu yönde içtihat oluşturmak suretiyle elektrik enerjisi nakil hatlarının neden olduğu zararı tazmin yükümlülüğünü kusursuz sorumluluk esasına dayandırarak çözümlemekteydi.

6098 sayılı Türk Borçlar Kanunu yürürlüğe girdikten sonra öğretide, elektrik enerjisi nakil vasıtalarının neden olduğu zarardan sorumluluğun TBK m. 71 hükmü uyarınca tehlike sorumluluğu esasına dayandırılması gerektiği ileri sürülmektedir ${ }^{91}$. Yargıtay uygulamasında ise kimi zaman sorumluluğun TBK $m$. 69 hükmü uyarınca yapı malikinin sorumluluğuna dayandııılı̆̆ı kimi zaman da sorumluluğun tehlike esasına dayandığına ilişkin genel ifadeler kullanılmak suretiyle elektrik enerjisi nakil vasıtalarının neden olduğu zarardan sorumluluğun objektif bir sorumluluk olduğunun ifade edilmesiyle yetinildiği görülmektedir.

\section{B. Sorumluluğun Türünün Belirlenmesi Bakımından Yapı Malikinin Sorumluluğu ve Tehlike Sorumluluğunun İncelenmesi}

\section{Yapı Malikinin Sorumluluğu}

Yapı malikinin sorumluluğu Türk Borçlar Kanununda bir kusursuz sorumluluk türü olarak düzenlenmiştir. Kusursuz sorumluluk kapsamında, yapı malikinin sorumluluğu öncelikle sebep olma esasına dayanmaktadır. Ancak sebep olma esası, kanun koyucunun kusur sorumluluğu ilkesinden ayrılması bakımından yeterli görülmemektedir $^{92}$. Dolayısıyla yapı malikinin sorumluluğu başka esaslara da dayandırımaktadır. Böylece kanun koyucunun kusur esasından ayrılmak suretiyle zararın tazmini ile yükümlü tuttuğu kişileri zarardan sorumlu tutabilmesinin dayanağını bu esaslar teşkil etmektedir ${ }^{93}$. Bu kapsamda yapı malikinin sorumluluğu, yararlanma ve hâkimiyet esaslarının yanı sıra tehlike esasına da dayanmaktadı ${ }^{94}$.

Türk Borçlar Kanunu'nda kusursuz sorumluluk hâlleri ise hakkaniyet sorumluluğu, özen sorumluluğu (objektif sorumluluk) ve tehlike sorumluluğu olmak üzere üç

91 NOMER, N. 121; YÜCEL, Özge: Türk Borçlar Kanununa Göre Genel Tehlike Sorumluluğu, Ankara 2014, s. 131; ÇEKIN, s. 63.

92 BAŞOĞLU, Başak: Sözleşme Dışı Kusursuz Sorumluluk Hukuku Ve Özellikle Tehlike Sorumluluğuna İlişkin Değerlendirmeler, İnönü Üniversitesi Hukuk Fakültesi Dergisi Cilt:6 Sayı 2 Yıl 2015, s. 33.

93 BAŞOĞLU, S. 34.

94 BAŞOĞLU, s. 35, dipnot 16. Tehlike esasına dayanması bakımından bkz. PICHONNAZ, Pascal/WERRO, Franz: La responnsabilité fondée sur le risque: un état des lieux et quelques perspectives d'avenir, (édité par WERRO, Franz/PICHONNAZ, Pascal) Colloque du droit de la responsabilité civile 2017, Université de Fribourg, Stämpfli Verlag AG 2018, s. 15. Yalnızca yararlanma esasına dayandığı yönünde bkz. OĞUZMAN, M. Kemal/ÖZ, M. Turgut: Borçlar Hukuku Genel Hükümler, C. II, İstanbul 2017, N. 517. 
tür altında sınıflandırılmıştır. Bu ayrıma göre yapı malikinin sorumluluğu özen sorumluluğu kapsamında düzenlenmiştir. Buna karşılık yapı malikine, kurutuluş kanıtı getirmek suretiyle sorumluluktan kurtulma imkânı tanınmamışı ${ }^{95}$. O nedenle yapı malikinin sorumluluğunun ağırlaştıııımış özen sorumluluğu (objektif sorumluluk) olduğu kabul edilmektedir ${ }^{96}$.

Türk Borçlar Kanunu m. 69/f.1 hükmünde yapı malikinin sorumluluğu, "bina veya diğer yapı eserlerinin maliki, bunların yapımındaki bozukluklardan veya bakımındaki eksikliklerden doğan zararı gidermekle yükümlüdür" şeklinde düzenlenmiştir. TBK m. 69/f.2 hükmünde ise bina veya diğer yapı eserinin bakımındaki eksiklikten, malik ile birlikte intifa hakkı ve oturma hakkı sahibinin müteselsilen sorumlu olduğu hüküm altına alınmıştır.

Yapı malikinin sorumluluğundan bahsedebilmek için; bir bina veya yapı eseri mevcut olmalı; bina veya yapı eserinin yapımında bozukluk ya da bakımında eksiklik bulunmalı; üçüncü bir kişi zarara uğramış olmalı; bina ya da diğer yapı eserinin yapımındaki bozukluk veya bakımındaki eksiklik ile zarar arasında uygun nedensellik bağı bulunmalı ve bina veya yapı eserinin maliki yahut intifa hakkı ya da oturma hakkı sahibi sorumlu kişi olmalıdır ${ }^{97}$.

Zararın varlığının yanı sıra zarar ile bina veya diğer yapı eserinin yapımındaki bozukluk veya bakımındaki eksiklik arasında nedensellik bağı bulunması, sorumluluğun genel koşullarını oluşturur. Bir bina veya diğer yapı eserinin bulunması; bina veya yapı eserinin yapımında bozukluk ya da bakımında eksiklik olması ve bina veya diğer yapı eserinin maliki yahut intifa hakkı ya da oturma hakkı sahibinin sorumlu kişi olması ise sorumluluğun özel koşullarıdır.

95 Oysa olağan özen sorumluluğu (objektif sorumluluk) bakımından sorumlu kişiye, objektif özen yükümünün gereği gibi yerine getirildiğinin veya gerekli özen gösterilseydi dahi zararın gerçekleşeceğinin ispatlanması hâlinde sorumluluktan kurtulma imkânı getirilmiştir (BAŞOĞLU, s. 39).

96 NOMER, Halûk: Borçlar Hukuku Genel Hükümler, İstanbul 2017, N. 121; BAŞOĞLU, s. 41. Olağan objektif sorumluluk olduğu yönünde bkz. CHAIX, François: La responsabilité civile du propriétaire de bâtiment (art. 58 CO), (Editörler: FOËX, Bénédict/HOTTELIER, Michel) Servitudes, droit de voisinage responsabilités du propriétaire immobilier, Genéve 2007, s. 40. Tehlike sorumluluğu olduğu yönünde bkz. KILIÇOĞLU, Ahmet M.: Borçlar Hukuku, Genel Hükümler, Ankara 2018, s. 461.

97 BURCUOĞLU, Halûk: Doğal Afetler Nedeniyle Oluşan Bedensel Zararlarda Bina ve Yapı Malikinin Sorumluluğu ile Yapıyı İnşa Eden Yüklenicinin Sorumluluğu, Yeni Gelişmeler Işığında Bedensel Zararların Tazmini Uluslararası Kongre, (Editörler: UÇAKHAN GÜLEÇ, Sema/ BASA, Necdet) Türkiye Barolar Birliği, Ankara 2016, s. 112; CHAIX, s. 40. 
Yapı eseri malikinin sorumluluğunun doğması bakımından, zarara neden olan bir bina ya da yapı eseri bulunmalıdır ${ }^{98}$. Öğreti ve uygulamada bina kavramı insanların, hayvanların ya da eşyaların korunması veya barınmasına tahsis edilmiş, bu amaca elverişli toprağa bağı ı yapı eseri olarak ifade edilmektedir ${ }^{99}$. Binanın dışındaki yapı eserleri ise toprakla doğrudan ya da dolaylı bağlantısı olan sabit ve insan faaliyeti ile yapılmış ya da değiştirilmiş (yapay olarak meydana getirilmiş) şeylerdir ${ }^{100}$. Bu tanım ekseninde; reklam tabelaları, köprüler, kanallar, barajlar, telefon ve elektrik direkleri, karayolları, tren ve tramvay rayları, banyo küvetleri, kombi ve şofbenler, inşaat iskeleleri, vinçler, asansörler, su kuyuları, su tesisatı, kanalizasyon tesisatı, merdivenler, yüzme havuzları, çocuk oyun parkları, açık ve kapalı spor tesisleri yapı eserine örnek gösterilmektedir ${ }^{101}$.

98 BURCUOĞLU, s. 112; ÖZTAŞ, Illker: 6098 sayılı Türk Borçlar Kanunu Açısından Yapı Malikinin Sorumluluğu, Cevdet Yavuz Anısına Armağan, 6098 Sayılı Türk Borçlar Kanunu Hükümlerinin Değerlendirilmesi Sempozyumu (3 - 4 Haziran 2011), Sempozyum Yayınları 2011, s. 179. 818 sayılı BK m. 58 hükmünde "bina veya imal olunan herhangi bir şey" ifadesinin değiştirilmiş olmasının isabetli olduğu yönünde bkz. KILIÇOĞLU, s. 461; ÖZTAŞ, s. 191.

99 WERRO, Franz: Comentaire Romand, Code des obligations I, Art.1-529, (Edité par THÉVENOZ, Luc/WERRO, Franz), Helbing Lichtenhahn Verlag, Basel 2012 [CR-CO], Art. 58, N. 6; WERRO, Franz: La responsabilité civile, Stämpfli Verlag AG 2017 [Responsabilité], N. 774; ; TANDOĞAN, Halûk: Türk Mesuliyet Hukuku Akit Dışı ve Akdi Mesuliyet, Ankara 1961, s. 186; OĞUZMAN/ÖZ, N. 522; ERTEN, Ali: Borçlar Kanunu ve Yapı Denetimi Hakkında KHK Açısından Türk Hukukunda Yapıların Neden Oldukları Zarardan Dolayı Sorumluluk, Ankara 2000 [Yapıların Neden Oldukları], s. 6; KILIÇOĞLU, s. 462; BURCUOĞLU, s. 112; ANTALYA, Gökhan: Borçlar Hukuku, Genel Hükümler, C. II, İstanbul 2015 [Borçlar Hukuku], s. 326.

100 WERRO, CR-CO, Art. 58, N. 7; WERRO, Responsabilité, N. 775; ; BREHM, Roland: Die Entstehung durch unerlaubte Handlungen, Art. 41 - 61 OR Schweizerisches Zivilgesetzbuch, Das Obligationenrecht, BK - Berner Kommentar, (Herausgeber: Hausheer, Heinz / Walter, Hans Peter), Stämpfli Verlag AG 2013, Art. 58, N. 26 vd.; GÖKSU, Tarkan: Präjudizienbuch OR Die Rechtsprechung des Bundesgerichts (1875-2015), (Herausgeber: GAUCH, Peter / AEPLI, Viktor/ STÖCKLI, Hubert ), Schulthess Juristische Medien AG 2016, Art. 58, N.6; FISCHER, Willi: OR Kommentar Schweizerisches Obligationenrecht OFK - Orell Füssli Kommentar (Herausgeber: Kostkiewicz, Jolanta Kren / Wolf, Stephan / Amstutz, Marc/ Fankhauser, Roland ) Orell Füssli Verlag AG 2016, Art. 58, N. 20; MÜLLER, Christof: Obligationenrecht - Allgemeine Bestimmungen Art. 1-183 OR, CHK - Handkommentar zum Schweizer Privatrecht, (Herausgeber: Furrer, Andreas / Schnyder, Anton K.), Schulthess Juristische Medien AG 2016, Art. 58, N. 3; TANDOĞAN, Mesuliyet, s. 187; OĞUZMAN/ÖZ, N. 523; KILIÇOĞLU, s. 462; ERTEN, Yapıların Neden Oldukları, s. 7; BURCUOĞLU, s. 112; ANTALYA, Borçlar Hukuku, s. 323.

101 BREHM, Art. 58, N. 45-46; GÖKSU, Art. 58, N.7; MÜLLER, Art. 58, N. 3; DESCHENAUX/TERCIER, s. 97; CHAIX, s. 47-49 ve s. 53-60; EREN, Fikret: Borçlar Hukuku Genel Hükümler, Ankara 2018, 675; OĞUZMAN/ÖZ, N. 523 ve N. 527; BURCUOĞLU, s. 112; ANTALYA, Borçlar Hukuku, s. 323; ERTEN, Ali: Türk Borçlar Kanunu'na Göre Bina ve İnşa Eseri Sahiplerinin Sorumluluğu (BK m. 58), Ankara 2000 [Bina ve İnşa Eseri], s. 117-118 ve s. 121-125. 
Yapı eserinin yapımındaki bozukluktan kasıt, bina ya da diğer yapı eserinde yapım ya da projelendirme aşamasında, diğer bir deyişle başlangıçta, bir eksiklik veya bozukluk olmasıdır ${ }^{102}$. Tamamlanmasından sonra tahsis edildiği amaca uygun olarak bina ya da diğer yapı eserinin kullanılmaya yahut yararlanılmaya elverişli hâlde tutulmaması ise bakımdaki eksikliktir ${ }^{103}$. Dolayısıyla, bir bina ya da diğer yapı eserinin yapımındaki bozukluk veya bakımındaki eksiklik değerlendirilirken, tamamlanmış olan söz konusu yapı eserinin tahsis amacı dikkate alınmalıdır ${ }^{104}$. Bu anlamda genel yaşam deneyimlerinden hareketle objektif bir değerlendirme yapılmalıdır ${ }^{105}$.

Yapı eserinin yapımı için gerekli izinlerin alınmamış olması yahut gerekli izinler alınmasına rağmen iznin kapsam ve sınırlarının aşılıı̧ olması hâli yapımdaki bozukluktur ${ }^{106}$. Gerekli izinler alınmış olan projeye aykırı biçimde yapının inşa edilmesi de bu kapsamda değerlendirilir ${ }^{107}$. Projede bulunan eklenti ya da bütünleyici parçanın yapı eserinde bulunmaması hâli de bu kapsamdadır ${ }^{108}$. Ayrıca yapı eserinin yapııdığı zaman mevcut olan teknik kurallara uygun olarak yapının inşa edilmemiş olması, yapımdaki bozukluktur ${ }^{109}$. Mevcut teknik kurallara uygun malzeme kullanılmaması ya da yeterli sayıda personel çalıştııımamış olması hâli yapımdaki bozukluğa örnek gösterilebilir ${ }^{110}$. Buna karşıık, yapı eseri tamamlandıktan sonra gelişen tekniğe uygun gerekli önlemlerin alınmamış olması hâli, yapı eserinin bakımında eksiklik teşkil eder ${ }^{111}$.

Yapı eseri tamamlandıktan sonra, teknik gelişmelere uygun olarak yapı eserinde gerekli iyileştirmelerin yapılmamış olması; yapı eserinin bozulan, eskiyen ve yıpranan kısımlarının zamanında onarılmamış olması yahut yapı eserinin tahsis edildiği

102 WERRO, Responsabilité, N. 793; EREN, 677.

103 WERRO, CR-CO, Art. 58, N. 17; EREN, s. 678; ERTEN, Bina ve Inş̧a Eseri, s. 100.

104 WERRO, Responsabilité, N. 798; BREHM, Art. 58, N. 48 ve 65; FISCHER, Art. 58, N. 29; GÖKSU, Art. 58, N.13; MÜLLER, Art. 58, N. 14 ve N.20; TANDOĞAN, Mesuliyet, s. 192; OĞUZMAN/ÖZ, N. 538; BURCUOĞLU; s. 113; ANTALYA, Borçlar Hukuku, s. 331; ERTEN, Bina ve İnşa Eseri, s. 135; BAŞ, s. 94.

105 WERRO, CR-CO, Art. 58, N. 18; WERRO, Responsabilité, N. 798; BREHM, Art. 58, N. 56; FISCHER, Art. 58, N. 28; GÖKSU, Art. 58, N.11; MÜLLER, Art. 58, N. 21.

TANDOĞAN, Mesuliyet, s. 192; KILIÇOĞLU, s.468; ANTALYA, Borçlar Hukuku, s. 332.

107 TANDOĞAN, Mesuliyet, s. 192; KILIÇOĞLU, s.468; ANTALYA, Borçlar Hukuku, s. 332; BAŞ, s. 96.

108 ERTEN, Bina ve İnşa Eseri, s. 132; BAŞ, s. 98.

109 BREHM, Art. 58, N. 58; TANDOĞAN, Mesuliyet, s. 191; ANTALYA, Borçlar Hukuku, s.332; BAŞ, S. 96.

110 EREN, s. 677; TEKINAY, Selahattin Sulhi / AKMAN, Sermet / BURCUOĞLU, Halûk/ALTOP, Atilla: Borçlar Hukuku Genel Hükümler, İstanbul 1993, s. 700; ANTALYA, s. 332.

111 ERTEN, Yapıların Neden Oldukları, s. 25. 
amaca uygun olarak gerekli koruma önlemlerinin alınmamış olması yapı eserinin bakımında eksiklik olarak değerlendirilir ${ }^{112}$.

Elektrik enerjisi nakil vasıtaları ile kastedilen iletken elektrik tellerini de içeren nakil hatlarıdır. Bu tanımdan hareketle elektrik enerjisi nakil vasıtaları mecra olarak kabul edilmektedir. Mecra kavramı, Türk Medeni Kanunu'nda tanımlanmamıştır. Öğretide ise mecra, gerek enerjinin gerekse maddelerin taşınması ve dağııılması amacıyla kullanılan teknik tesisat olarak tanımlanmaktadır ${ }^{113}$. Ayrıca gerek öğretide gerekse uygulamada su, gaz, elektrik, buhar ve petrol gibi enerji ve maddelerin taşınması için kullanılan tesisat mecra olarak kabul edilmektedir ${ }^{114}$.

Hâliyle kimi Yargıtay kararlarında elektrik enerjisi nakil vasıtaları, yapı eseri olarak kabul edilmek suretiyle, bu hatların yapımındaki bozukluk ya da bakımındaki eksiklik nedeniyle doğan zarardan yapı maliki olarak nakil hattının geçtiği arazinin maliki yahut varsa mecra irtifakı sahibi sorumlu tutulmaktadır.

\section{Tehlike Sorumluluğu}

Tehlike sorumluluğunda tehlike esası ön plandadır ${ }^{115}$. Tehlike sorumluluğu, sorumluluk türlerinin en ağııını oluşturur. Zira sorumluluk bakımından kusurdan veya objektif özen ya da gözetim ödevinin ihlalinden bağımsızdır ${ }^{116}$. Diğer bir deyişle, tehlikeli işletmenin sahibi ya da işletenin kusurlu olup olmaması, özen ödevini yerine getirip getirmemesi, işletmede bir bozukluk ya da eksikliğin olup olmaması meydana gelen zarardan sorumluluğun doğması bakımından hiçbir önem ve etkiye sahip değildir $^{117}$. Tehlikenin gerçekleşmesi ile sorumluluk doğar ${ }^{118}$.

Pierre Widmer ve Pierre Wessner tarafından hazırlanan İsviçre Sorumluluk Hukukunda Yeknesaklaştırma ve Revizyona Iliş̧in Ön Tasarı'da (Widmer/Wessner TasarIsı) genel bir tehlike sorumluluğu hükmü düzenlenmiştir. Bu ön tasarı, İsviçre sorumluluk hukukunda reform ile sonuçlanmamış ve yasalaşmamış olmakla birlikte; gerek

112 EREN, s. 678; ERTEN, Bina ve İņ̧a Eseri, s. 143; KILIÇOĞLU, s. 469; ANTALYA, Borçlar Hukuku, s. 333.

113 OĞUZMAN, Kemal/SELiçi, Özer/OKTAY-ÖZDEMiR, Saibe, Eşya Hukuku, İstanbul 2017, N. 1832; SiRMEN, Lale: Eşya Hukuku, Ankara 2017, s. 394.

114 OĞUZMAN/SELIÇi/OKTAY-ÖZDEMIR, N. 1832; SIRMEN, s. 394.

115 PICHONNAZ/WERRO, s. 13.

116 EREN, s. 521; BAŞOĞLU, s. 44.

117 PICHONNAZ /WERRO, s. 17; EREN, s. 521.

118 BAŞOĞLU, s. 44. Özellikle karakteristik tehlikenin meydana gelmesiyle sorumluluğun doğması yönünde bkz. PICHONNAZ/WERRO, s. 17. 
6098 sayılı Türk Borçlar Kanunu'nun tehlike sorumluluğunu düzenleyen hükmüne ${ }^{119}$ gerekse 2020 İsviçre Borçlar Kanunu tasarısındaki tehlike sorumluluğunun düzenlendiği hükme ${ }^{120}$ esin kaynağı olmuştur. Nitekim tehlike sorumluluğunun genel hükümle ele alındığı 2020 tasarısı m. 60/f.1 hükmü uyarınca, "önemli ölçüde tehlikeli bir faaliyette bulunan kişi, bu faaliyetin karakteristik riskinin (tehlikesinin) gerçekleşmesi sonucunda doğan zarardan sorumludur". 2020 Tasarısı m. 60/f.2 hükmünde ise önemli ölçüde tehlikeli faaliyetten ne anlaşılması gerektiği ifade edilmiştir. Buna göre "gerekli bütün özen gösterilse dahi mahiyeti icabı yahut kullanılan malzeme, araç ve güçler nedeniyle ağır veya sıklıkla zarara yol açmaya elverişli faaliyet, önemli ölçüde tehlikeli faaliyettir". Her iki fıkra birlikte değerlendirildiğinde, yalnızca karakteristik tehlikenin (riskin) gerçekleşmesi hâlinde önemli ölçüde tehlikeli faaliyeti yerine getirenin sorumlu tutulduğu görülmektedir ${ }^{121}$. İsviçre hukukunda tehlike sorumluluğunun genel hükümle düzenlendiği tasarı henüz yasalaşmamıştır. Buna karşılık Türk hukuk düzeninde 6098 sayılı Türk Borçlar Kanunu'nda kusursuz sorumluluk başlığı altında m. 71 ile tehlike sorumluluğu genel hükümle düzenlemeye kavuşmuştur ${ }^{122}$. TBK m. 71/f.1 hükmü, "önemli ölçüde tehlike arz eden bir işletmenin faaliyetinden zarar doğduğu takdirde, bu zarardan işletme sahibi ve varsa işleten müteselsilen sorumludur" şeklindedir.

Türk Borçlar Kanunu m. 71 hükmünde tehlike kavramı, iki ayrı anlamda kullanılmaktadır: IIlk anlamıyla tehlike, zararın gerçekleşme intimalinin yüksekliği ve sıklığını; ikinci anlamıyla ise, gerçekleşmesi muhtemel zararın büyüklüğünü, ağılığını ve yoğunluğunu ifade eder ${ }^{123}$. TBK $m$. 71 hükmü çerçevesinde her somut olayda işletme

119 Genel olarak 6098 Sayılı Borçlar Kanunu'nun Haksız Fiillere ilişkin kısmının hazırlanmasında Widmer/Wessner tasarısından kaynak olarak kullanıldığı yönünde bkz. ANTALYA, Gökhan: Sorumluluk Hukukunda Yeni Gelişmeler, MÜHFD C. 14, S. 4, YIl 2008, s. 66 [Sorumluluk].

120 FELLMANN Walter/ MÜLLER, Christoph/ WERRO, Franz: Schweizer Obligationenrecht 2020 Entwurf für einen neuen allgemeinen Teil / Code des obligations suisse 2020 - Projet relatif à une nouvelle partie générale Année 2013, (Herausgeber: HUGUENIN, Claire/ HILTY, Reto M.), Art 60 CO 2020, Zürich 2013, N. 1.

121 PICHONNAZ/WERRO, s. 18.

122 Belirtmek gerekir ki, TBK m. 71/f. 3 hükmünde, belirli bir tehlike hâli için öngörülen özel sorumluluk hükümlerinin saklı olduğu ifade edilmiştir. Bu suretle kanun koyucunun düzenleme yapması hâlinde, özel bir kanunla düzenlenmiş olan tehlike sorumluluğu hâlleri öncelikle uygulama alanı bulacaktır (ERDEM, Mehmet: Türk Borçlar Kanunu Uyarınca Tehlike Sorumluluğu, Prof. Dr. Cevdet Yavuz’a Armağan, 6098 sayılı Türk Borçlar Kanunu Hükümlerinin Değerlendirilmesi Sempozyumu (3-4 Haziran 2011), Sempozyum Yayınları 2011, s. 208).

123 EREN, s. 527; TiFTiK, Mustafa, Türk Hukukunda Tehlike Sorumluluklarının Genel Kural ile Düzenlenmesi, Yetkin Yayınları, Ankara 2005, s. 31-32; AKKAYAN YILDIRIM, Ayça: 6098 Sayılı Türk 
faaliyetinin tehlikeli olup olmadığı hâkim tarafından takdir edilecektir ${ }^{124}$. TBK m. 71/f.2 hükmünde hâkime yol göstermek amacıyla önemli ölçüde tehlike arz eden işletmenin belirlenmesi bakımından birtakım kıstaslar getirilmiştir. Buna göre, bir işletmenin mahiyeti veya faaliyette kullanılan malzeme, araçlar ya da güçler dikkate alındığında bu işlerde uzman bir kişiden beklenen tüm özen gösterilse dahi, sıkça veya ağır zarar doğurmaya elverişli ise önemli ölçüde tehlike arz eden bir işletmeden söz edilir ${ }^{125}$. TBK m. 71/f.2 hükmü doğrultusunda işletmenin mahiyeti, faaliyetinde kullandığı malzeme, araçlar ve güçlerin niteliği gereği bu konuda uzman olan kişiler tarafından gerekli tüm özen gösterilmesine rağmen sık sık ve ağır tehlikelere neden olması hâlinde, işletme faaliyetinin önemli ölçüde tehlike arz ettiği sonucuna varılmaktadır ${ }^{126}$. Önemli ölçüde tehlike arz eden işletmenin tespitinde bir objektif bir de sübjektif iki unsurdan yararlanılır. Objektif unsur, tehlikenin herhangi bir faaliyetin arz ettiği normal tehlikeyi aşan yoğunlukta olmasıdır ${ }^{127}$. Bu unsur, TBK m. 71/f. 2 hükmünde işletme faaliyetinin sık sık ve ağır zararlar doğurmaya elverişli olması şekline ifade edilmiştir ${ }^{128}$. Sübjektif unsur ile kast edilen ise sorumlu tutulan kişinin özen göstermeme şeklindeki davranışından bağımsız olarak işletme faaliyetinin zarara yol açması yani tehlikenin kaçınılmaz olmasıdır ${ }^{129}$. TBK m. 71 hükmünde bu unsur, uzman bir kişiden beklenen tüm özenin gösterilmesi hâlinde dahi işletme faaliyetinin zarar doğurmaya elverişli olması ifadesine karşılık gelmektedir ${ }^{130}$. Ayrıca herhangi bir ka-

Borçlar Kanunu Düzenlemeleri Çerçevesinde Kusursuz Sorumluluğun Özel Bir Türü Olarak Tehlike Sorumluluğu, iÜHFM, C. LXX, S. 1, 2012, s. 210.

124 KILIÇOĞLU, s. 481;YÜCEL, s. 109; SARAÇ, Senem: Türk Borçlar Kanunu'nda Tehlike Sorumluluğu, İstanbul 2013, s. 46; AKKAYAN-YILDIRIM, s. 210.

125 Hükümde esas alınan "faaliyetin tehlikeliliği" kıstası yerine, "faaliyetin yürütülmesinde ihtiyaç duyulan nesnelerin tehlikeliliği" kıstasının getirilmesi ve düzenlemeden "mahiyeti" deyiminin çıkarılmasıyla bu amaca ulaşılması mümkün olduğu ileri sürülmüştür (bkz. BÜYÜKSAĞiş, Erdem: "Tehlike Esasına Dayanan Genel Sorumluluk Kuralı Üzerine Eleştirel Değerlendirmeler", DEÜHFD, Cilt 8, Sayı 1, Yıl 2006, s. 10).

126 EREN, s. 527; ERDEM, s. 210.

127 ANTALYA, Borçlar Hukuku, s. 366; ERDEM, s. 210; BÜYÜKSAĞiş, s. 4; YÜCEL, s. 124; ÇEKIN, s. 184; SARAÇ, s. 36.

128 ANTALYA, Borçlar Hukuku, s. 366; ERDEM, s. 210; SARAÇ, s. 36.

129 ANTALYA, Borçlar Hukuku, s. 366; ERDEM, s. 210; BÜYÜKSAĞiş, s. 5; YÜCEL, s. 126; ÇEKIN, s. 184.

130 ANTALYA, Borçlar Hukuku, s. 366; ERDEM, s. 211; SARAÇ, s. 36. 
nunda benzeri tehlike arz eden işletmeler için özel tehlike sorumluluğu öngörülmüşse, bu işletmeler de önemli ölçüde tehlike arz eden işletme sayılır (TBK m. $71 / f .2)^{131}$.

Belirtmek gerekir ki, TBK m. 71/f.1 hükmü uyarınca sorumluluktan bahsedebilmek için, bir işletme faaliyetinden zararın doğmuş olması gerekir ${ }^{132}$. Zira kanun koyucu, herhangi bir ürünün, eşyanın ya da faaliyetin tehlikeli olması hâli bakımından sorumluluk öngörmemiştir ${ }^{133}$. Hâliyle bireysel faaliyetler neticesinde doğan zararlar bu kapsamda değerlendirilmez ${ }^{134}$. Ne var ki, hükmün uygulanması bakımından esnaf işletmesi ya da ticari işletme ile sınırlı kalınmamalıdır ${ }^{135}$. Bu doğrultuda TBK m. 71 hükmü anlamında işletme faaliyeti, "cismani bir tehlike kaynağından doğan, belirli bir teknik risk içeren ve belirli bir menfaat amacıyla örgütlenme çerçevesinde yürütülen faaliyet" olarak tanımlanabiliir ${ }^{136}$. Tehlike sorumluluğu bakımından önemli olan, işletmenin önemli ölçüde tehlike arz eden bir faaliyet yürütmesidir ${ }^{137}$. Türk Borçlar Kanunu $\mathrm{m} .71$ anlamında, önemli ölçüde tehlike arz eden faaliyet teknik risk içeren bir faaliyet olmalıdır ${ }^{138}$. Ayrıca önemli ölçüde tehlike arz eden bir işletmenin verdiği her türlü zararı tazmin yükümlülüğü, TBK m. 71 hükmü kapsamında değerlendirilemez ${ }^{139}$. Zira TBK m. 71/f.2 hükmü ile uzman kişi tarafından tüm özen gösterilse dahi önlenemeyecek zarar, tehlike sorumluluğu kapsamında tazmin edilmesi gereken zarardır. Önemli ölçüde tehlike arz eden işletme faaliyetinin neden olduğu her türlü zarar değil

131 Burada bir varsayım kabul edildiği yönünde bkz. ULUSAN, İlhan: Türk Borçlar Kanununda Yer Alan Genel Tehlike Sorumluluğu Kuralına İlişkin Birkaç Tespit ve Hukuk Düzeni Tarafından Faaliyetine İzin Verilmiş Önemli Ölçüde Tehlike Arzeden İşletmelerin Yol Açtığı Zararların Uygun Bir Bedelle Denkleştirilmesi Sorunu, Journal of Yaşar University, Cilt: 8, Özel Sayı, Prof. Dr. Aydın Zevkliler'e Armağan, 2013 [Denkleştirme Sorunu], s. 2900; ANTALYA, Borçlar Hukuku, s. 362.

132 EREN, s. 526; KILIÇOĞLU, s. 480; NOMER, N. 123.2; ANTALYA, Borçlar Hukuku, s. 367; ERDEM, s. 210. Bu sınırlamanın isabetli olmadığı yönünde bkz.; ULUSAN, Denkleştirme Sorunu, s. 2899; ATAMER, Yeşim: Revize Edilmiş Türk Borçlar Kanunu Tasarısına Iliş̧kin Değerlendirme ve Teklifler, Hukuki Perspektif Dergisi, Sayı: 6, Mayıs 2006, s. 22; AKKAYAN YILDIRIM, s. 209. OĞUZMAN/ÖZ, N. 578.

134 ERDEM, S. 210.

135 EREN, s. 526; KILIÇOĞLU, s. 481; NOMER, N. 123.2; ERDEM, s. 210; YÜCEL, s. 114; ÇEKIN, s. 202; SARAÇ, s. 34.

136 Ayrıntılı inceleme için bkz. YÜCEL, s. 114-118; ÇEKIN, 184-208.

137 ERDEM, s. 210.

138 ÇEKIN, s. 198 ve 230. Dolayısıyla faaliyetin doğal riskleri tehlike sorumluluğu kapsamında değerlendirilmez (ERDEM, s. 211).

139 NOMER, N. 123.1; ERDEM, s. 212. 
ve fakat karakteristik riskin neden olduğu zarar tehlike sorumluluğu kapsamında tazmin edilmelidir ${ }^{140}$.

Türk hukukunda tehlike sorumluluğunda nedensellik bağına ilişkin tartışmalar bulunmaktadır. Oysa tehlike sorumluluğunda nedensellik bağı, özellikle sorumluluğun sınırlandırılması bakımından diğer sorumluluk türlerine göre daha büyük önem arz etmektedir ${ }^{141}$. Zira tehlike sorumluluğu, haksız bir olguya değil ve fakat önemli ölçüde tehlike arz eden işletme faaliyetinin gerçekleşmesi şeklinde tehlikeli bir olguya bağlıdır ${ }^{142}$. Ayrıca tehlike sorumluluğunda önemli ölçüde tehlikeli faaliyeti yürütenin kusuru aranmaz ${ }^{143}$. Bir görüşe göre tehlike sorumluluğunda, sorumluluğun kurulması ve sınırlandırıması bakımından uygun nedensellik bağı teorisi esas alınmalıdır ${ }^{144}$. Buna göre önemli ölçüde tehlike arz eden işletmenin yürüttüğü tehlikeli faaliyet ile gerçekleşen zarar arasında uygun illiyet bağının bulunması tehlike sorumluluğu için yeterlidir ${ }^{145}$. Bu kapsamda zarar görenin kusuru ağır ise illiyet bağını kesebilir ${ }^{146}$. Ne var ki, üçüncü kişinin kusuru ağır ise yahut mücbir sebep söz konusu ise illiyet bağının

140 OĞUZMAN/ÖZ, N. 579; ANTALYA, Borçlar Hukuku, s. 367; NOMER, N. 123.1; YÜCEL, s. 143; ÇEKIN, s. 225-230. Karakteristik risk ifadesi yerine tipik tehlike ya da tipik risk kavramı da kullanılmaktadır. Bkz. TiFTiK, s. 31 vd.; EREN, s. 526-527; ERIŞGiN, Nuri: Tehlike Bağı, http://dergiler.ankara.edu.tr/dergiler/38/292/2662.pdf (Erişim Tarihi: 25.05.2019), s. 145; SARAÇ, s. 62; AKKAYAN YILDIRIM, s. 210. Tipik tehlikenin varlı̆̆ının aranması gerektiği yönünde bkz. EREN, s. 526-527; SARAÇ, s. 6-642. Tipik riskin bulunması gerektiği yönünde bkz. AKKAYAN YILDIRIM, s. 210. TBK m. 71 hükmünde karakteristik risk ifadesi yer almasa dahi karakteristik rizikonun gerçekleşmesinin zarara yol açmadığı hâllerde tehlike sorumluluğu söz konusu olmaz (YÜCEL, s. 143). Ayrıca Widmer/Wessner tasarısında tehlike sorumluluğunun düzenlendiği m. 50 hükmünde açıkça karakteristik riskin yol açtığı zarar ifadesine yer verilmiştir. 6098 Sayılı Türk Borçlar Kanunu tasarısında tehlike sorumluluğunun düzenlendiği hükmün ilk hâli, Widmer/Wessner tasarısında ile paraleldir. Sonrasında her ne kadar karakteristik risk ifadesi 6098 Sayılı Türk Borçlar Kanunu tasarısında tehlike sorumluluğunun düzenlendiği hükümden çıkarılmış ve TBK m. 71 hükmü bu şekliyle yasalaşmışsa da hükmün amaca uygun olarak yorumlanması gerekir (ERDEM, s. 212).

141 ÇEKIN, s. 218.

142 EREN, S. 527.

143 YÜCEL, s. 180-181.

144 TANDOĞAN, Halûk, Tehlike Sorumluluğu Kavramı, Sorumluluk Hukukunda Yeni Gelişmeler Sempozyumu II, ìstanbul 1981, s. 7 vd. [Yeni Gelişmeler]; ULUSAN, IIlhan, Tehlike Sorumluluğu Üstüne, MHAD, Yıl 4, No.6, 1970, s. 55 vd. [Tehlike]; EREN, s. 528; ANTALYA, Borçlar Hukuku, s. 362; SARAÇ, s. 57 vd.; TiFTiK, s. 35.

145 TANDOĞAN, Yeni Gelişmeler, s. 7 vd.; ULUSAN, Tehlike, s. 55 vd.; EREN, s. 528; ANTALYA, Borçlar Hukuku, s. 362; SARAÇ, s. 57 vd.; TiFTiK, s. 35.

146 EREN, s. 528; TiFTiK, s. 37-39. 
kesildiği mutlak surette kabul edilmemeli ve fakat somut olaya göre değerlendirilme$\operatorname{lidir}^{147}$. Bir başka görüşe göre ise, tehlike sorumluluğunda sorumluluğun sınırlandırılması bakımından normun koruma amacı teorisi esas alınmalıdır ${ }^{148}$. Buna göre, tehlike sorumluluğunda karakteristik risk hem sorumluluğu kurmakta hem de sınıllandırmaktadır ${ }^{149}$. Nedensellik bağının kesilmesi bakımından öncelikle karakteristik riskin gerçekleşip gerçekleşmediği dikkate alınmalıdır. Zira karakteristik riskin gerçekleşmediği hâlde nedensellik bağını kesen olguların ispatına intiyaç duyulmaz ${ }^{150}$. Zarar görenin kusuru ağır olduğu yahut karakteristik risk zarar görenin etki alanında gerçekleştiği takdirde nedensellik bağının kesildiğinden söz edilebilir ${ }^{151}$. Ne var ki, karakteristik riskin yoğunluğu dikkate alınmalıdır. Bazı hâllerde önemli ölçüde tehlike arz eden işletme faaliyetindeki karakteristik risk o kadar yoğundur ki, artık zarar görenin kusurlu davranışının karakteristik risk ile zarar arasındaki nedensellik bağını kestiğinden bahsedilemez ${ }^{152}$. Üçüncü kişinin kusuru da ağır ise yahut karakteristik risk üçüncü kişinin etki alanında gerçekleşmiş ise, yine karakteristik riskin yoğunluğu değerlendirilerek, üçüncü kişinin davranışının karakteristik risk ile zarar arasında nedensellik bağını kestiğinden söz edilebilir ${ }^{153}$. Karakteristik riskin gerçekleşmesi hâlinde mücbir sebebin nedensellik bağını kestiğinden hareketle sorumluluktan kurtulmanın mümkün olmadığı, zira tehlike sorumluluğunun amacının alınan bütün önlemlere karşın tehlikenin önüne geçilememesi nedeniyle önemli ölçüce tehlike arz eden işletme faaliyetinin neden olduğu zarardan işletme sahibinin yahut işletenin sorumlu tutulması olduğu ileri sürülmüştür ${ }^{154}$. Özellikle ağır zararlara yol açmaya elverişli önemli ölçüde tehlike arz eden işletme faaliyeti bakımından, mücbir sebebin karakteristik risk ile zarar arasındaki nedensellik bağını kesmesinin neredeyse imkânsız olduğu kabul edilmekte$\operatorname{dir}^{155}$.

147 Hatta soruna dikkatle yaklaşılması gerektiği yönünde bkz. EREN, s. 528.

148 YÜCEL, s. 162; ÇEKIN, s. 219-222. Normun koruma amacı teorisinin tehlike bağı şeklinde nitelendirilerek açıklanması yönünde bkz. ERIşGiN, s. 144-148.

149 ÇEKIN, s. 230. Aynı yönde fakat tipik tehlike kavramı üzerinden yapılan açıklamalar için bkz. ERIŞGIN, s. 149-151.

150 YÜCEL, s. 165; ÇEKIN, s. 244.

151 YÜCEL, S. 169.

152 YÜCEL, S. 169.

153 YÜCEL, S. 172.

154 ÇEKIN, S. 246.

155 YÜCEL, S. 166. 


\section{Yargıtay’ın Elektrik Enerjisi Nakil Hatlarının Yol Açtı̆̆ı Zarardan Sorumluluğa} Yaklaşımı

818 sayılı Borçlar Kanunu'nun yürürlükte olduğu dönemde Yargıtay'ın yerleşik içtihatlarında, elektrik enerjisi nakil hatlarının neden olduğu zarardan sorumluluk 818 sayılı BK m. 58 hükmüne dayandırılmaktaydı ${ }^{156}$. Bu dönemdeki Yargıtay kararlarında, enerji nakil vasıtalarının can ve mal güvenliği açısından tehdit oluşturduğu, tehlikeli yapılar olduğu vurgulanmakta ve yapı eserinin bakımındaki eksiklik yahut yapımındaki bozukluk nedeniyle tesis sahibinin sorumlu olduğu ifade edilmektedir. Bu konuda özellikle Yargıtay Hukuk Genel Kurulu'nun 2003 yılında verdiği bir karar önem arz etmektedir ${ }^{157}$. Karara konu olayda, "uçurtması elektrik nakil hattına takılan çocuğun akıma kapılarak ölmesi nedeniyle anne ve babası maddi ve manevi zararlarının tazminini talep etmiştir". Illk derece mahkemesi tarafından, "olayın çocuğun uçurtmasının tele takılması nedeniyle meydana geldiği ve o sebeple ölen çocuğun \%100 kusurlu olduğu ifade edilmek suretiyle enerji nakil hattı sahibinin kusuru olmadığından zarardan sorumlu olmadığı ve kusursuz sorumluluk şartlarının oluşmadığı" yönünde karar tesis edilmiştir. Yargıtay 4. Hukuk Dairesi, dosya kapsamında, "yalnızca enerji nakil hattının yapımında bozukluk olup olmadığının incelenmesini yetersiz bulmuş, tesis sahibinin bu olaydan önce tele takılı bulunan uçurtmanın başkaları tarafından alınması sırasında doğan tehlikeyi düşünerek hatta gereken denetimi yaparak bu tür engelleri kaldırması gerekirken, bu konuda özensiz davranması itibariyle sorumlu olduğu" gerekçesiyle kararı bozmuştur. Direnme üzerine önüne gelen uyuşmazlıkta Hukuk Genel Kurulu, "bilirkişi raporlarına göre davalının bir yapım bozukluğunun bulunmadığı belirtilmekte ise de, olayların gidişatından insanların ve canlıların yaşamı için önemli bir tehdit oluşturan bu tür tesislerin bakım ve korunmasında, tesisin yerleşim yeri üzerinde bulunduğu da düşünüldügünde, normalin üzerinde bir özen borcu bulunduğu sonucuna varılır. Davalı elektrik idaresi bu tür yüksek gerilim iletkenlerine güvenli yaklaşma sınırının aşılmamasını sağlayıı önlemleri almalı, gerekli uyarı levhalarını herkesin kolay-

156 Yarg. 4.HD T. 14.01.2014, 2013/19147 E.-2014/228 K. (www.lexpera.com.tr, erişim tarihi: 18.03.2019); Yarg. 4 HD T.01.10.2014, 2014/58483E.-2014/12830K. (www.corpus.com.tr, erişim tarihi: 20.09.2018); Yarg. 3 HD 11.02.2013, 2012/18838E.-2013/1876K. (www.corpus.com.tr, erişim tarihi: 20.09.2018); Yarg. 4. HD T. 10.03.2009, 2008/6930E- 2009/3469K.; Yarg. 4.HD T. 19.2.2009, 2008/7431E.- 2009/2359K.; Yarg. 21. HD T. 17.05.2007, 2006/20422E.- 2007/8277K.; Yarg. 4.HD T. 28.06.2005, 2004/13024 E.- 2005/7173K.; Yarg. HGK, T. 12.03.2003, 2003/4-144E.- 2003/161K.; Yarg. 4.HD T.06.11.2001, 2001/5698E.2001/10834K. (www.lexpera.com.tr, erişim tarihi: 18.03.2019).

157 Yarg. HGK, T. 12.03.2003, 2003/4-144E.- 2003/161K. (www.lexpera.com.tr, erişim tarihi: 18.03.2019). 
Iıkla görebileceği yerlere koymalı, bu tesislerin can ve mal güvenliğine zarar vermemesi için, yerleşim yeri dışındaki tesislere oranla çok daha kısa aralıklarla kontrollerini yapmalıdır. Ne var ki, somut olayda davalı idarenin bu bakım ve özen borcunu gereği gibi yerine getirmediği, söz konusu olaydan önce tele takılı bulunan uçurtmanın başkaları tarafından alınması sırasında doğabilecek tehlikeleri düşünerek, gereken denetimleri yaparak, bu tür engelleri kaldırmadığı anlaşıldığından, meydana gelen zarardan sorumlu olduğu, sorumluluğu kaldıracak nedenlerin ise bulunmadığı" yönünde hüküm kurmuştur ${ }^{158}$.

6098 Sayılı Türk Borçlar Kanunu yürürlüğe girdikten sonraki Yargıtay içtihatlarını gruplandırmak gerekirse, büyük bir kısmında, enerji nakil hatlarının tehlike içerdiğine işaret edilmekle birlikte elektrik nakil vasıtalarının yol açtığı zarardan sorumluluk TBK m. 69 hükmü uyarınca yapı malikinin sorumluluğuna dayandırılmaktadır ${ }^{159}$.

Elektrik nakil hattındaki tellerin tutuşması ve kıvılcımların tarladaki ürünleri yakması ile ilgili bir kararında Yargıtay, elektrik nakil hatlarının yapı eseri olduğunun altını çizerek, TBK m. 69 hükmü uyarınca yapı eserinin bakımındaki eksiklikten enerji nakil vasıtası sahibinin sorumlu olduğu şeklinde karar vermiştir ${ }^{160}$.

Elektrik enerjisi nakil vasıtasından geçen elektriğe kapılan bir kişinin uğradığı bedensel zararın tazminine ilişkin bir uyuşmazılıkta Yargıtay, hem TBK m. 69 hem de TBK $m$. 71 hükümlerine atıf yapmış ve enerji nakil vasıtasının sahibinin bu yapı eserinin fena yapılmasından, bakımı ve işletilmesindeki eksikliklerden sorumlu olduğu; bu tür nakil vasıtalarının kişilerin can ve mal güvenliği açııından tehlike arz etmeyecek şekilde inşa etmek, bulundurmak ve bu hatlara güvenli yaklaşma sınııının aşılmasını önleyecek tedbirleri almakla yükümlü olduğundan hareketle enerji nakil vasıtası sahibinin ağır özen yükümlülüğ̈nnün ihlali nedeniyle sorumlu tutulması yönünde karar tesis etmiştir ${ }^{161}$.

\footnotetext{
158 Hatta daha sonra pek çok kararda bu karara atıf yapılmaktadır. Bkz. Yarg. 4. HD T. 25.09.2012, 2011/10485E. 2012/13468K. (www.corpus.com.tr, erişim tarihi: 20.09.2018).

159 Yarg. 3. HD T. 31.05.2016, 2015/16137E.-2016/8587K.; Yarg. 3. HD, T. 19.04.2016, 2016/5938E.-2016/6068K.; Yarg. 3. HD T. 16.03.2016, 2015/7031E.- 2016/3998K.; Yarg. 3. HD T. 16.02.2016, 2016/135E.- 2016/1986K.; Yarg. 3. HD T. 26.09.2016, 2015/15388E.2016/11182 K.; Yarg. 3. HD T. 21.12.2015, 2015/1137E.-2015/20626K.; Yarg. 3. HD T. 12.4.2016, 2015/8685E.-2016/5628K. (www.lexpera.com.tr, erişim tarihi: 18.03.2019).

160 Yarg. 4 HD T.26.09.2016, 2015/15388E.-2016/11182K. (www.lexpera.com.tr, erişim tarihi: 18.03.2019).

161 Yarg. 4 HD T.17.06.2017, 2016/6701E.-2017/17400K.; Yarg. 4 HD T.21.12.2015, 2015/1137E.2014/20626K. (www.lexpera.com.tr, erişim tarihi: 18.03.2019).
} 
Yargıtay, elektrik nedeniyle çıkan yangınla ilgili olarak vermiş olduğu kararlarının bazılarında, "enerji nakil hattı sahibi bulunan davalı tehlike arz eden bu yapı eserinin fena yapılmasından, bakım ve eksikliklerinden sorumludur. Bu sorumluluk, niteliği itibariyle kusura dayanmayan (objektif) bir sorumluluktur" yönünde hüküm tesis etmiştir ${ }^{162}$. Bu suretle enerji nakil vasıtaları, tehlike arz eden yapı eseri olarak kabul edilmekte ve bu vasıtaların neden olduğu zarardan sorumluluğun türü açıkça ifade edilmeden genel olarak objektif sorumluluk esasına dayandığı belirtilmektedir.

Buna karşılık elektriğin sebep olduğu yangına ilişkin diğer Yargıtay kararlarında ${ }^{163}$ davalının bölgede elektrik enerjisinin dağıtımını yerine getirdiği; bu faaliyetin, varlığı ve niteliği itibariyle bir tehlike ve dolayısıyla zarar intimali taşıdığı ve davalının sorumluluğunun bir sebep sorumluluğu olan kusursuz (objektif) sorumluluk olduğu ifade edilmiştir. Bu sorumluluk türünün tehlike sorumluluğu olarak da isimlendirilmekte olduğu ve sorumluluk türlerinin en ağırını oluşturduğu; burada tehlikeli nesne veya işletmeyle gerçekleşen zarar arasında uygun illiyet bağının bulunmasının sorumluluk için gerekli olduğu ve hareket unsurunu haksız fiilin sonuç unsuruyla birlikte değerlendirmek gerektiği belirtilmiştir. Hatta "sorumlu kişinin veya işletmenin, kusurlu olup olmaması, özen ödevini yerine getirip getirmemesi, işletme veya nesnede (şeyde) bir bozukluk veya noksanın bulunup bulunmaması, meydana gelen zararın tazmin borcu yönünden bir etkiye sahip olmadığı vurgulanmıştır. Zira bunların sebep oldukları zararlarda, kusurun bulunup bulunmadığı ya da rolünün olup olmadığı çoğu zaman bilinemediği veya ispat edilemediği gibi, sorumlu kişi veya işletme, her türlü özeni gösterse, gözetim ve denetim ödevini yerine getirse, gerekli bütün tedbirleri alsa bile, gene çoğu zararın meydana gelmesini önlemek mümkün değildir. Bu sebeple sorumIuluğunun bağlandığı olguyla zarar arasında uygun illiyet bağı kurulduğu zaman, sorumluluk da gerçekleşmiş olacağından, bu işletme veya nesnelerin sahip veya işletenleri, bunların sebep oldukları zararı gidermek zorundadır" ifadeleri ile davalı elektrik enerjisi nakil hattı tesisi sahibinin kusursuz sorumluluk esasına göre sorumlu olması yönünde karar verilmiştir.

162 Yarg. 3 HD T.03.11.2015, 2014/21155E.-2015/17124K.; Yarg. 3. HD T. 27.02.2013, 2013/1403 E. 2013/3188 K. (www.lexpera.com.tr, erişim tarihi: 18.03.2019).

163 Yarg. 3 HD 03.11.2015, 2014/20465E.-2015/17103K. (www.corpus.com.tr, erişim tarihi: 20.09.2018)423; Yarg. 4 HD T.17.06.2014, 2014/4403E.-2014/9751K. (www.lexpera.com.tr, erişim tarihi: 18.03.2019); Yarg. 3 HD T.17.06.2014, 2014/4430E.-2014/9752K. (www.corpus.com.tr, erişim tarihi: 20.09.2018); Yarg. 3 HD 05.11.2014, 2014/6427E.-2014/14466K. (www.corpus.com.tr, erişim tarihi: 20.09.2018). 
Yargıtay kararlarındaki öncelikli kaygının, elektrik enerjisi nakil vasıtalarının neden olduğu zarardan sorumluluğun kusursuz sorumluluk kapsamında değerlendirilmesi olduğu görülmektedir ${ }^{164}$. Zira değinilen Yargıtay kararlarında ısrarla elektrik enerjisi nakil vasıtalarının neden olduğu zarardan sorumluluğun, kusur sorumluluğu kapsamında değerlendirilmemesi gerektiği ve objektif (kusursuz) sorumluluk kapsamında olduğunun altı çizilmektedir. Ne var ki, Yargıtay elektrik enerjisi nakil hatlarının neden olduğu sorumluluğu kusursuz sorumluluk kapsamında kabul etmekle birlikte kusursuz sorumluluğun dayandığı esas ile kusursuz sorumluluğun türü arasında bir ayrım yapmayarak, kimi kararlarda hem tehlike sorumluluğu hem de yapı malikinin sorumluluğunu düzenleyen hükümlere atıf yapmaktadır.

\section{Elektrik Enerjisi Nakil Hatlarının Yol Açtığı Zarardan Sorumluluğun Türünün ve Sorumlu Kişilerin Belirlenmesi}

\section{Sorumluluğun Türü}

Elektrik nakil hatları, yalnızca havadan elektrik direkleri üzerinden elektriğin taşınması faaliyeti şeklinde anlaşıımamalıdır. Elektriğin yerin altında yahut suyun altında da nakli mümkündür. Dolayısıyla bu çalışma kapsamında elektriğin yerin üstünde ya da yerin altında taşınması arasında fark gözetilmemektedir. Bu doğrultuda elektrik enerjisi nakil hatlarından kasıt, elektrik enerjisinin gerek iletimi gerek dağııımı gerekse bağlantı kablolarından taşınması için kullanılan iletken elektrik tellerini içeren nakil hatlarıdır. Yukarıda da ifade edildiği üzere, elektrik enerjisi nakil hatları mecra olarak kabul edildiğinden yapı eseri olarak değerlendirilmesi mümkündür. Ne var ki, sorumluluğun türünün belirlenmesi bakımından önemli olan elektrik enerjisi nakil faaliyetinin önemli ölçüde tehlike arz eden bir işletme faaliyeti olup olmadığının belirlenmesidir.

Yukarıda da ifade edildiği üzere TBK m. 71 hükmünde ifade edilen "önemli ölçüde tehlike arz etme" şartı, somut olayda bir işletmenin fiilen tehlike yaratmış olmasıyla değil, işletmenin niteliğinin ve faaliyetinin tehlike yaratmaya her zaman yatkın olmasıyla gerçekleşir ${ }^{165}$. İkinci olarak, "önemli ölçüde zarar tehlikesinin varlığı"; işletmenin niteliği, işletmede kullanılan malzeme, kullanılan araçlar ya da güçler göz önünde tutulmak kaydıyla, "bu işlerde uzman bir kişiden beklenen azami özenin gösterilmesi hâlinde bile işletmenin faaliyetinin sık veya ağır zararlar doğurmaya elverişli"

\footnotetext{
164 Bu kaygının kökeni, ilk derece mahkemesi kararlarında elektrik enerjisi nakil vasıtası sahibinin kusurunun bulunmadığından hareketle hüküm tesis ediliyor olmasıdır. Bkz. Yarg. HGK, T. 12.03.2003, 2003/4-144E.- 2003/161K. (www.lexpera.com.tr, erişim tarihi: 18.03.2019).

165 OĞUZMAN/ÖZ, N. 579.
} 
olması hâlinde söz konusu olur ${ }^{166}$. "Tehlikeli güç" kavramına örnek olarak, genellikle elektrik enerjisi verilmektedir ${ }^{167}$. Bu güç tehlikelidir, zira sık ve ağır zararlar doğurmaya elverişlidir.

Elektrik nakil faaliyeti Türkiye' de iletim ve dağıtım faaliyeti olarak yürütülmektedir. Elektrik Piyasası Kanunu m. 4 uyarınca elektrik iletim faaliyeti ve dağıtım faaliyeti Elektrik Piyasası Kanunu hükümleri uyarınca lisans alınmak kaydıyla yürütülebilir. EPK m. 8/f.1 hükmü uyarınca elektrik enerjisi iletim faaliyeti münhasıran Türkiye Elektrik İletim A.Ş. (TEIAŞ) tarafından yürütülmektedir. Enerji Piyasası Kanunu m. 9 hükmüne göre ise dağıtım faaliyeti, dağıtım şirketi tarafından lisansında belirlenen bölgede yürütülür. Dağıtım faaliyeti, dağıtım lisansında belirtilen bölge içinde tekel olarak yürütülmektedir. Dolayısıyla elektrik enerjisi nakil faaliyeti, cismani bir tehlike kaynağından doğan, belirli bir teknik risk içeren ve belirli bir menfaat amacıyla örgütlenme çerçevesinde yürütülen bir işletme faaliyetidir.

Elektrik enerjisinin depolanması mümkün olmadığından üretilen elektrik enerjisi, iletken teller üzerinden sürekli olarak nakledilmektedir. Bu faaliyet gerilim seviyesi dikkate alınarak, iletim ve dağıtım şeklinde ifade edilmektedir. Sorumluluğun türünün tayini bakımından ise iletim ve dağıtım şeklinde bir ayrımdan ziyade hangi gerilim düzeyinin önemli ölçüde tehlikeli olup olmadığının tespiti gerekir. Elektrik enerjisi nakil faaliyeti bakımından karakteristik tehlike nakil hattından sürekli elektrik geçmesi ve belirli bir mesafede yaklaşılması hâlinde insan bedeni yahut iletken olan herhangi bir cismin elektrik akımına kapılması şeklinde kendini gösterir. Benimsediğimiz görüş uyarınca, bu karakteristik tehlike ile zarar arasında illiyet bağının bulunması gerekir.

Elektrik Kuvvetli Akım Tesisi Yönetmeliği m. 4/a-2 hükmünde alçak gerilim, "etkin değeri 1000 volt ya da 1000 voltun altında olan fazlar arası gerilim";m. 4/a-3 hükmünde yüksek gerilim, "etkin değeri 1000 voltun üstünde olan fazlar arası gerilim" şeklinde tanımlanmıştır. Elektrik Kuvvetli Akım Tesisi Yönetmeliği m. 4/a-4 hükmünde ise tehlikeli gerilim, "etkin değeri, alçak gerilimde 50 voltun üstünde olan, yüksek gerilimde hata süresine bağlı olarak değişen gerilim" olarak ifade edilmiştir. Buna göre 50 voltun üzerinde olan gerilim her hâlde tehlikeli gerilimdir. Burada İsviçre hukukunda benzer bir yaklaşım olduğu görülmektedir. 50 voltun altındaki gerilimin ise tehlikeli olup olmadığı değerlendirilmemiştir. Bu hâlde İsviçre hukukundakine paralel bir şekilde, 50 voltun altındaki gerilime sahip tesislerin kural olarak tehlikeli olmadığı ka-

\footnotetext{
166 EREN, s. 526; KILIÇOĞLU, s. 482; SARAÇ, s. 36 vd.

167 KILIÇOĞLU, s. 482; TIFTIK, s. 33; YÜCEL, s. 129; SARAÇ, s. 49.
} 
bul edilebilir. Ne var ki bu tesislere kuvvetli akımın karışma tehlikesinin olduğu hâllerde, 50 voltun altındaki gerilime sahip tesisler de tehlikeli kabul edilmeli ve her somut olaya göre değerlendirme yapılmalıdır.

Bu açıklamalar ışığında, somut olayda objektif ve sübjektif unsurların bulunması hâlinde, elektrik enerjisi nakil işi 50 voltun üzerindeki gerilime sahip tesisler bakımından önemli ölçüde tehlikeli bir faaliyettir. Somut olayda 50 voltun üzerinde gerilime sahip bir elektrik enerjisi hattı üzerindeki nakil faaliyeti, herhangi bir faaliyeti aşan yoğunlukta tehlike arz ediyorsa ve sorumlu tutulan kişi tarafından her türlü özen gösterilse dahi kaçınılmaz ise önemli ölçüde tehlikeli faaliyet olarak kabul edilmelidir. Bu doğrultuda insan bedeni yahut iletken bir cismin elektrik akımına kapılması hususu değerlendirilebilir. Akıma kapılma bakımından yaklaşma mesafesi iş güvenliği ve iş sağlı̆ına ilişkin düzenlemelerde gerilim altındaki iletken ya da iletken olmayan teçhizatlara ilişkin yaklaşma mesafelerine göre tespit edilebilir. TEiAŞ İ̧ Sağlığı ve Güvenliği Yönetmeliği ${ }^{168} \mathrm{~m}$. 10 hükmünde, TEIASŞ güvenli çalışma mesafeleri ifade edilmiştir. Bu kapsamda belirlenmiş azami yaklaşım mesafeleri gerilim değerine göre, "1.000 15.000 volt arası $66 \mathrm{~cm}$.; $15.001-36.000$ volt arası $82 \mathrm{~cm}$.; $59.000-72.500$ volt arasi110cm.; 140.000 - 170.000 volt arasl 155 cm.; 200.000 - 250.000 volt arasi 213 cm. ve 340.000 - 420.000 volt arası 352 cm." olarak tespit edilmiştir. Yönetmelik hükmünün devamında verilen aralıklar dışındaki gerilimlerde işletilen yüksek gerilim teçhizatları için bir üst değerin kullanılacağı ifade edilmiştir. TEDAŞ Türkiye Elektrik Dağıtım Anonim Şirketi Genel Müdürlüğü Iş Güvenliği Yönergesi' ${ }^{169} \mathrm{~m} .7 /(1)$ uyarınca çalışanlar için gerilim altındaki iletkenlerde kabul edilen mutlak yaklaşma mesafesi , "O1000 Volta kadar $30 \mathrm{~cm}$; 1001-10000 Volta kadar $60 \mathrm{~cm}$.; 10001-36000 Volta kadar $90 \mathrm{~cm}$." olarak belirlenmiştir. iletkenlerin hareketli olması hâlinde bu mesafelerin iletkenin en fazla hareket durumuna göre asgari olarak korunacağı da belirtilmiştir. Somut olayda yapılan değerlendirme sonunda 50 voltun üzerinde gerilime sahip elektrik nakil hattından elektrik nakli faaliyetinin önemli ölçüde tehlikeli faaliyet olduğu sonucuna varılırsa, söz konusu faaliyet nedeniyle doğan zarardan sorumluluk TBK m.71 hükmü kapsamında tehlike sorumluluğu uyarınca tayin edilmelidir.

50 volt gerilimin altındaki tesislerin tehlikeli olup olmadığı da yine somut olaya göre değerlendirilmelidir. Yukarıda da ifade edildiği üzere, 50 volt gerilimin altındaki tesisler kural olarak tehlikeli kabul edilmez. Ancak kuvvetli akımın karışması intimali

168 https://www.teias.gov.tr/sites/default/files/2018-

11/\%C4\%B0\%C5\%9F\%20Sa\%C4\%9FI\%C4\%B1\%C4\%9F\%C4\%B1\%20ve\%20G\%C3\%BCvenli\%C 4\%9Fi\%20Y\%C3\%B6netmeli\%C4\%9Fi.pdf (erişim tarihi: 21.05.2019).

169

http://www.tedas.gov.tr/sx.web.docs/tedas/docs/yonergeler/is_guvenligi_yonergesi.doc (erişim tarihi: 21.05.2019). 
olan hâllerde, elektrik enerjisi nakli faaliyetinin önemli ölüde tehlikeli olup olmadığı objektif ve sübjektif unsur değerlendirilmek suretiyle hâkim tarafından takdir edilmelidir. Önemli ölçüde tehlike arz ettiği sonucuna varılması hâlinde söz konusu tesislerin neden oluğu zarardan sorumluluk TBK m. 71 hükmü uyarınca tayin edilmelidir.

Karakteristik tehlikenin gerçekleşmesi hâlinde karakteristik tehlikenin yoğunluğu dikkate alınarak, karakteristik tehlike ile zarar arasında illiyet bağının kesilip kesilmediği meselesi değerlendirilebilir. Zarar görenin veya üçüncü kişinin davranışı, bu kişilerin kusuru ağır ise yahut karakteristik risk üçüncü kişinin etki alanında gerçekleşmiş ise bu kişilerin davranışının karakteristik risk ile zarar arasında nedensellik bağını kestiğinden söz edilebilir. Mücbir sebep bakımından somut olaya göre değerlendirme yapılması gerekmektedir. Ne var ki, özellikle ağır zararlara yol açmaya elverişli önemli ölçüde tehlike arz eden işletme faaliyeti bakımından ki, 36kV (36.000 volt) gerilime sahip iletim faaliyeti bu kapsamda değerlendirilebilir, mücbir sebebin karakteristik risk ile zarar arasındaki nedensellik bağını kesmesinin olanaksız olduğu kabul edilmelidir.

Tehlikeli olmadığı sonucuna varılan 50 volt gerilimin altındaki tesisler nedeniyle doğan zarardan sorumluluk ise koşulları varsa TBK m. 69 hükmü uyarınca yapı malikinin sorumluluğu kapsamında değerlendirilebilir. Buna göre söz konusu nakil hatları mecra niteliğinde olduğundan yapı eseri olarak kabul edilmektedir. Bu yapı eserinin yapımında bozukluk ya da bakımındaki eksiklik olması, zararın meydana gelmiş olması ve bu yapı eserinin yapımındaki bozukluk ya da bakımındaki eksiklik ile zarar arasında uygun nedensellik bağının bulunması hâlinde, TBK m. 69 hükmüne göre sorumluluk tayin edilir. Bu hükmün uygulama alanına girmeyen hâllerde ise TBK m. 49 hükmü uyarınca kusur sorumluluğu esasına dayanılarak sorumluluk tayin edilmelidir.

\section{Sorumlu Kişiler}

Türk Borçlar Kanunu m. 71/f.1 uyarınca önemli ölçüde tehlike arz eden işletme faaliyetinden doğan zarardan, işletme sahibi ve varsa işleten sorumludur ${ }^{170}$. Iş̧letme sahibi ve işletenin ayrı kişiler olması hâlinde müteselsil sorumlulukları söz konusu olacaktır ${ }^{171}$. Bu işletmeyi işletenin ya da işletme sahibinin kamu otoritesi ya da kamu kurumu olması önemli değildir. O nedenle kamu tüzel kişilerine ait olan kamusal nitelikli işletmeler de önemli ölçüde tehlikeli bir faaliyeti yürütüyorlarsa TBK m.71 hükmünün

170 İşletmenin sahibi dışında bir başkası tarafından, örneğin kiracı tarafından işletilmesi hâlinde bu kişi işleten sıfatıyla sorumlu olmaktadır (OĞUZMAN/ÖZ, N. 582; KILIÇOĞLU, s. 484; ERDEM, s. 213).

171 OĞUZMAN/ÖZ, N. 582; KILIÇOĞLU, s. 484; SARAÇ, s. 116 vd.; YÜCEL, s. 212 vd. 
kapsamında sorumlulukları tayin edilir ${ }^{172} .50$ volt gerilim üzerindeki nakil tesislerinden elektrik nakli önemli ölçüde tehlike arz eden bir faaliyet olarak değerlendirilirse, tehlike sorumluluğu kapsamında tesis sahibi ve işleten incelenmelidir.

Yukarıda da ifade edildiği üzere, EPK m. 8/f.1 hükmü uyarınca elektrik enerjisi iletim faaliyeti, doğal tekel özelliği göstermektedir ve ülkemizde bu tekel TEIAŞ’a aittir $^{173}$. Yukarıda da ifade edildiği üzere iletim tesislerindeki gerilim 36 kV'ın üzerinde olduğundan iletim hatlarından elektrik nakli tehlikeli bir faaliyettir. Iletim hatlarının gerek sahibi gerekse işleteni olan TEIAŞ, bu tesislerin neden olduğu zarardan sorumludur. Zira EPK m. 8/f.3 hükmü uyarınca TEiAŞ'ın mülkiyet ve işletme sınırı, iletim sistemine yapılan bağlantı noktasında başlar. Ayrıca üretim veya tüketim tesisinin iletim sistemine bağlantısının, bir başka üretim veya tüketim tesisine ait şalt sahası üzerinden yapılması hâlinde bağlantı yapılan fiderin kullanım hakkı, işletme ve bakımı TEIAŞ'a aittir (EPK m. 8/f.3). Üretim tesislerinden yeraltı kabloları ile iletim tesisine kadar elektrik nakli de bu kapsamdadır.

Enerji Piyasası Kanunu m. 9 hükmüne göre dağıtım faaliyeti, dağııım lisansında belirtilen bölge içinde tekel olarak yürütülmektedir. Örneğin, AYEDAŞ, Başkent Elektrik Dağııım A.Ş., Gediz Elektrik Dağıtım A.Ş. gibi. Yukarıda da ifade edildiği üzere dağıtım tesislerindeki gerilim 36 kV'ın altındadır. O hâlde 50 voltun üzerinde olan dağııım hatlarından elektrik enerjisi nakli, tehlikeli faaliyet teşkil etmektedir. Dağıtım tesislerinin sahibi, TEiAŞ olmakla birlikte işleteni işletme hakkını usulüne uygun dağııım lisansı ile alan kişidir. Dolayısıyla dağııım tesislerinin neden olduğu zarardan TEIAŞ ve dağıtım lisansı sahibi kişi müteselsilen sorumludur.

Yukarıda da ifade edildiği üzere gerilimi 50 voltun altında olan ve somut olayın değerlendirilmesi sonucu kuvvetli akımın karışması tehlikesinin olmadığı nakil tesislerinin neden olduğu zarardan sorumluluk TBK m. 69 hükmü uyarınca tayin edilebilir. Zira söz konusu nakil hatları mecra niteliğinde olup TBK m. 69 hükmü kapsamında yapı eseri olarak kabul edilir. Mecralar, üstünde veya altında bulunduğu taşınmaza hizmet etmek amacı ile kurulmuşsa arazinin bütünleyici parçası sayılır, bu anlamda istisnai bir özellik arz etmez. Ancak eğer mecra, fiziki anlamda bağlı bulunduğu taşınmaza hizmet etmiyor, başka bir teşebbüse hizmet edip yalnızca üstünde veya altında bulunduğu taşınmazdan geçiyor ise bu durumda o taşınmazın bütünleyici parçası sayılmaz. Mecranın mülkiyeti, kurulan mecra irtifakı yolu ile taşınmazdan ayrıştırıır, hizmet ettiği teşebbüsün malikine ait olur.

172 OĞUZMAN/ÖZ, N. 578; KILIÇOĞLU, s. 481; YÜCEL, s. 202; AKKAYAN YILDIRIM, s. 211.

173 YAVUZ, s. 22. 
TMK m. 744 hükmünde su, kurutma kanalı, gaz ve benzerlerine ait borular, elektrik hat ve kabloları mecra kapsamında ifade edilmiştir. TMK m. 727/f.1 hükmü uyarınca su, gaz, elektrik ve benzerlerinin mecraları işletmenin bulunduğu taşınmazın dışında olsa bile, aksine bir düzenleme olmadıkça, o işletmenin eklentisi olarak kabul edilmiş ve işletme malikinin malı sayılmıştır. Bunun için işletme sahibi lehine bir mecra irtifakı kurulmuş olmalıdır ${ }^{174}$. Böylece aksine bir düzenleme olmadıkça, mecra olarak nitelendirilen yapıların maliki, mecra irtifakı sahibi olmaktadır ${ }^{175}$. O nedenle bu yapıların yapımındaki bozukluk ya da bakımındaki eksiklik nedeniyle meydana gelen zararlardan mecra irtifakı sahibi sorumludur ${ }^{176}$.

\section{SONUÇ}

Elektrik doğada bulunan birincil enerji kaynağının dönüştürülmesi sonucunda elde edilen ikincil bir enerji kaynağıdır. Güç üretiminin yanı sıra ısı ve ışık kaynağı olarak da kullanılan elektrik depolanamamaktadır. O nedenle üretilen elektrik şebekeye aktarılmakta ve enerji nakil hatları üzerinde taşınmaktadır. Üretilen elektrik enerjisi, öncelikle üretim tesisinin 36kV (36.000 volt) üstü gerilim seviyesi ile bağlı olduğu iletim tesisine aktarılmakta ve bu tesislerde taşınmaktadır. Iletim hatlarındaki yüksek voltajlı elektrik enerjisi, doğrudan kullanıma uygun olmadığından öncelikle dağıtım için uygun voltaj seviyesine indirilmekte ve ortak ve alçak gerilim seviyesinde iletim tesisinden tüketiciye, dağıtım tesisleri aracılığıyla taşınmaktadır.

Üretilen elektrik enerjisinin, aktarılmasını ve taşınmasını sağlayan elektrik nakil hatlarından sürekli elektrik enerjisi geçmektedir. O nedenle bu hatların neden olduğu zararlar, kimi zaman ölüm gibi geri dönülemez bazen ciddi bir yaralanma gibi ağırdır. Kimi zaman da elektrik enerjisi nakil hatları yangına sebep olmak suretiyle geniş alana yayılan büyük ölçekli zararlara yol açmaktadır.

Incelenen hukuk düzenlerinden İsviçre hukuku ve Alman hukukunda elektrik nakil hatlarından enerji taşınması faaliyeti, tehlikeli bir faaliyet olarak kabul edilmiş ve

174 Şayet komşuluk ilişkisine ilişkin hükümler uyarınca komşu taşınmazdan mecra geçiriliyorsa o takdirde, ortada zorunlu bir mecra irtifakı vardır (SIRMEN, s. 394). Buna göre, başka yerden geçirilmesi olanaksız veya aşırı derecede masrafı ise mecranın komşu taşınmazın altından ya da üstünden geçirilmesi söz konusu olmaktadır (TMK m. 744).

175 Komşuluk ilişkisini düzenleyen hükümleri uyarınca mecra irtifakının kurulmamış olması hâlinde iradi bir mecra irtifakı söz konusu olur ve taraflar mecranın mülkiyetinin işletme sahibine değil de arazi malikine ait olacağını serbestçe kararlaştırabilir (OĞUZMAN/SELiçi/OKTAYÖZDEMIR, N. 1840).

176 TANDOĞAN, Mesuliyet, s. 165; ERTEN, Bina ve İnşa Eseri, s. 159; ANTALYA, Borçlar Hukuku, s. 317; ÖZTAŞ, s. 184. 
özel kanunlarda sorumluluk rejimi öngörülmüştür. İsviçre hukukunda EleG m. 27 hükmünde zayıf ve kuvvetli akım tesislerinin yol açtığı ölüm, beden bütünlüğünün ihlali ve şeye verilen zarardan sorumluluk kusursuz sorumluluk hâli olarak düzenlenmiştir. 50 voltun üzerinde gerilime sahip olan tesisler, kuvvetli akım tesisi olarak nitelendirilmiş ve bu tesislerin neden olduğu zarardan sorumluluk EleG m. 27 hükmü uyarınca kusursuz sorumluluğun asıl uygulama alanı kapsamında kabul edilmiştir. 50 voltun altında gerilime sahip olan tesisler ise zayıf akım tesisleri olarak kabul edilmiş ve bu tesislerin neden olduğu zarardan sorumluluk kaideten EleG m. 27 hükmü uyarınca kusursuz sorumluluğun uygulama alanı dışında bırakılmıştır. Ancak kuvvetli akım tesisi ile karışma ihtimali olan hâllerde zayıf akım tesislerinin yol açtığı zarardan sorumluluk, EleG m. 27 hükmü kapsamında değerlendirilmektedir. Alman hukukunda da elektrik enerjisi tesisinin faaliyeti esnasında meydana gelen ölüm, beden bütünlüğünün ihlali yahut bir şeye (eşyaya) verilen zarar nedeniyle tesis sahibinin sorumluluğu kusursuz sorumluluk şeklinde düzenlenmiştir. Buna karşılık, Alman hukukunda zayıf ya da kuvvetli akım şeklinde bir ayrım yapılmamıştır.

İtalyan hukukunda elektrik enerjisi nakil hatlarının neden olduğu zarardan sorumluluğa ilişkin özel bir kanunla sorumluluk rejimi öngörülmemiştir. Bu tesislerin yol açtığı zarardan sorumluluk it.MK m. 2050'de ifadesini bulan tehlike esasına dayalı sorumluluğa göre tayin edilir. Hükümde açıkça sorumluluğun kusur esasına dayandığı yahut kusursuz sorumluluk türü olduğu ifade edilmemiştir. O nedenle öğretide bu sorumluluğun kusursuz sorumluluk olduğu kabul edilmektedir. Ne var ki, uygulamada sorumlu kişi aleyhine kusur karinesinin mevcut olduğu ifade edilmektedir. Yüksek gerilim hatlarından elektrik taşınması, tehlikeli bir faaliyet olarak kabul edilmektedir. Alçak gerilim hattından elektrik taşınması hâlinde ise idarenin düzenlediği güvenlik önlemlerinin alınmadığı durumda faaliyet tehlikeli olarak değerlendirilmektedir.

Incelenen hukuk düzenlerinde özellikle elektrik enerjisi nakli esnasında elektrik enerjisinin neden olduğu zarardan sorumluluğun ele alındığı görülmektedir. İsviçre ve Alman hukukunda elektrik enerjisi tesisinin faaliyette olduğu esnada meydana gelen zarardan sorumluluk özel olarak kusursuz sorumluluk kapsamında düzenlenmiştir. Alman hukukunda elektrik enerjisinin yol açtığı zarardan sorumluluk ile elektrik enerjisi geçmeyen tesisin yol açtığı zarardan sorumluluğun farklı düzenlendiği görülmektedir. Elektrik enerjisinin yol açtığı zarardan sorumluluktan kurtulmak ancak mücbir sebep hâlinde mümkündür. Ancak elektrik enerjisinden bağımsız olarak yalnızca tesisin zarara neden olması durumunda tesislerin hukuka uygun olması hâli, sorumluluktan kurtulma sebebi olarak kabul edilmiştir. İsviçre hukukunda ise kuvvetli ya da zayıf akım tesislerinin yol açtığı zarardan sorumluluk elektrik tesisinin faaliyeti esnasında zarar meydana gelmişse kusursuz sorumluluk olarak tayin edilmiştir. Mücbir sebep, 
üçüncü kişinin kusuru yahut zarar görenin kusuru illiyet bağını kesecek ağırlıkta ise sorumluluktan kurtulma hâli olarak kabul edilmiştir.

Elektrik nakil hatlarının yol açtığı zarardan sorumluluğa ilişkin Türk hukukunda özel bir kanuni düzenleme bulunmamaktadır. O nedenle Türk Borçlar Kanunu'ndaki genel hükümlere göre sorumluluk belirlenmelidir. Kanaatimizce, 50 voltun üzerinde gerilime sahip hatlardan elektrik enerjisinin taşınması, objektif ve sübjektif unsurların somut olayda değerlendirilmesi suretiyle önemli ölçüde tehlikeli faaliyet olması sonucuna varılıyorsa, söz konusu nakil hatlarının yol açtığı zarardan sorumluluk TBK m. 71 hükmü uyarınca tehlike sorumluluğuna göre tayin edilmelidir. 50 voltun altında gerilime sahip nakil hatlarının neden olduğu zarardan sorumluluk ise somut olaya göre değerlendirilmeli ve kuvvetli akımın karışması ihtimalinin olduğu hâllerde yine objektif ve sübjektif unsurlar değerlendirilmek suretiyle önemli ölçüde tehlike arz eden faaliyet olarak kabul edilmesi hâlinde TBK m. 71 hükmü uygulanmalıdır. Elektrik enerjisi nakil faaliyeti bakımından karakteristik tehlike nakil hattından sürekli elektrik geçmesi ve belirli bir mesafede yaklaşılması hâlinde insan bedeni yahut iletken olan herhangi bir cismin elektrik akımına kapılması şeklinde kendini gösterir. Benimsediğimiz görüş uyarınca, bu karakteristik tehlike ile zarar arasında illiyet bağının bulunması gerekir. Karakteristik tehlikenin gerçekleşmesi hâlinde karakteristik tehlikenin yoğunluğu dikkate alınarak, karakteristik tehlike ile zarar arasında illiyet bağının kesilip kesilmediği meselesi değerlendirilebilir. Zarar görenin veya üçüncü kişinin davranışı, bu kişilerin kusuru ağır ise yahut karakteristik risk üçüncü kişinin etki alanında gerçekleşmiş ise bu kişilerin davranışının karakteristik risk ile zarar arasında nedensellik bağını kestiğinden söz edilebilir. Mücbir sebep bakımından somut olaya göre değerlendirme yapılması gerekmektedir. Ne var ki, özellikle ağır zararlara yol açmaya elverişli önemli ölçüde tehlike arz eden işletme faaliyeti bakımından ki, 36Kv (36.000 volt) gerilime sahip iletim faaliyeti bu kapsamda değerlendirilebilir, mücbir sebebin karakteristik risk ile zarar arasındaki nedensellik bağını kesmesinin olanaksız olduğu kabul edilmelidir.

50 voltun altında gerilime sahip nakil hatlarının yapımındaki bozukluk yahut bakımındaki eksiklik nedeniyle zararın meydana gelmesi hâlinde sorumluluk TBK m. 69 hükmüne göre tayin edilmelidir. Buna göre söz konusu nakil hatları mecra niteliğinde olduğundan yapı eseri olarak kabul edilmektedir. Bu yapı eserinin yapımında bozukluk ya da bakımındaki eksiklik olması, zararın meydana gelmiş olması ve bu yapı eserinin yapımındaki bozukluk ya da bakımındaki eksiklik ile zarar arasında uygun nedensellik bağının bulunması hâlinde, TBK m. 69 hükmüne göre sorumluluk tayin edilir. Bu hükmün uygulama alanına girmeyen hâllerde ise TBK m. 49 hükmü uyarınca kusur sorumluluğu esasına dayanılarak sorumluluk tayin edilmelidir. 


\section{KAYNAKLAR}

AKKAYAN YILDIRIM, Ayça: 6098 Sayılı Türk Borçlar Kanunu Düzenlemeleri Çerçevesinde Kusursuz Sorumluluğun Özel Bir Türü Olarak Tehlike Sorumluluğu, iÜHFM, C. LXX, S. 1, 2012, s. 203-220.

ANTALYA, Gökhan: Sorumluluk Hukukunda Yeni Gelişmeler, MÜHFD C. 14, S. 4, Yıl 2008, s. 63-83 [Sorumluluk].

ANTALYA, Gökhan: Borçlar Hukuku, Genel Hükümler, C. II, İstanbul 2015 [Borçlar Hukuku].

AYRANCl, Hasan: Enerji Sözleşmeleri, Ankara 2010.

BAŞ, Ece: 6098 Sayılı Borçlar Kanunu Açısından Bina veya Yapı Eserlerinden Doğan Sorumluluk TBK m. 69 (BK m. 58), ìstanbul 2011.

BAŞOĞLU, Başak: Sözleşme Dışı Kusursuz Sorumluluk Hukuku Ve Özellikle Tehlike Sorumluluğuna İlişkin Değerlendirmeler, İnönü Üniversitesi Hukuk Fakültesi Dergisi Cilt:6 Sayı 2 Yıl 2015, s. 29-56.

BREHM, Roland: Die Entstehung durch unerlaubte Handlungen, Art. 41 - 61 OR Schweizerisches Zivilgesetzbuch, Das Obligationenrecht, BK - Berner Kommentar, (Herausgeber: Hausheer, Heinz / Walter, Hans Peter), Stämpfli Verlag AG 2013.

BURCUOĞLU, Halûk: Doğal Afetler Nedeniyle Oluşan Bedensel Zararlarda Bina ve Yapı Malikinin Sorumluluğu ile Yapıyı İnşa Eden Yüklenicinin Sorumluluğu, Yeni Gelişmeler Işığında Bedensel Zararların Tazmini Uluslararası Kongre, (Editörler: UÇAKHAN GÜLEÇ, Sema/ BASA, Necdet) Türkiye Barolar Birliği, Ankara 2016.

BÜYÜKSAĞiş, Erdem: "Tehlike Esasına Dayanan Genel Sorumluluk Kuralı Üzerine Eleştirel Değerlendirmeler", DEÜHFD, Cilt 8, Sayı 1, Yıl 2006, s. 1-21.

CHAIX, François: La responsabilité civile du propriétaire de bâtiment (art. 58 CO), (Editörler: FOËX, Bénédict/HOTTELIER, Michel) Servitudes, droit de voisinage responsabilités du propriétaire immobilier, Genéve 2007.

COMPORTI, Marco: II Codice Civile Commentario, Fatti illeciti: le responsabilità oggettive, Artt. 2049-2053, Giuffrè Editore, 2009.

ÇEKIN, Mesut Serdar: 6098 Sayılı Türk Borçlar Kanunu Madde 71 Çerçevesinde Tehlike Sorumluluğu, İstanbul 2016.

DESCHENAUX Henri/TERCIER, Pierre: Sorumluluk Hukuku, (Çev. ÖZDEMIR, Salim), Ankara, 1983. 
ERDEM, Mehmet: Türk Borçlar Kanunu Uyarınca Tehlike Sorumluluğu, Prof. Dr. Cevdet Yavuz’a Armağan, 6098 Sayılı Türk Borçlar Kanunu Hükümlerinin Değerlendirilmesi Sempozyumu (3-4 Haziran 2011), Sempozyum Yayınları 2011, s. 217-226.

ERIŞGiN, Nuri: Tehlike Bağı, http://dergiler.ankara.edu.tr/dergiler/38/292/2662.pdf (Erişim Tarihi: 25.05.2019).

ERTEN, Ali: Borçlar Kanunu ve Yapı Denetimi Hakkında KHK Açısından Türk Hukukunda Yapıların Neden Oldukları Zarardan Dolayı Sorumluluk, Ankara 2000 [Yapıların Neden Oldukları].

ERTEN, Ali: Türk Borçlar Kanunu'na Göre Bina ve İnşa Eseri Sahiplerinin Sorumluluğu (BK m. 58), Ankara 2000 [Bina ve İnşa Eseri].

FELLMANN, Walter: Schweizerisches Haftpflichtrecht Band I bis III - eine Bilanz zum gesetzgeberischen Handlungsbedarf, (Herausgeber: FELLMANN, Walter/ WEBER, Stephan), Haftpflichtprozess HAVE, Schulthess Juristische Medien AG 2016 [HAVE].

FELLMANN Walter/ MÜLLER, Christoph/WERRO, Franz: Schweizer Obligationenrecht 2020 Entwurf für einen neuen allgemeinen Teil / Code des obligations suisse 2020 - Projet relatif à une nouvelle partie générale Année 2013, (Herausgeber: HUGUENIN, Claire/ HILTY, Reto M.), Art 60 CO 2020, Zürich 2013.

FILTHAUT, Werner: Haftpflichtgesetz, Kommentar zur Haftpflichtgesetz und zu den konkurrierenden Vorschriften anderer Haftungsgesetze, 9. Völlig neu bearbeitete Auflage 2015, C.H. Beck, München.

FISCHER, Willi: OR Kommentar Schweizerisches Obligationenrecht OFK - Orell Füssli Kommentar (Herausgeber: Kostkiewicz, Jolanta Kren / Wolf, Stephan / Amstutz, Marc/ Fankhauser, Roland) Orell Füssli Verlag AG 2016.

GALGANO, Francesco: Diritto Privato, CEDAM 2017.

GÖKSU, Tarkan: Präjudizienbuch OR Die Rechtsprechung des Bundesgerichts (18752015), (Herausgeber: GAUCH, Peter / AEPLI, Viktor/ STÖCKLI, Hubert), Schulthess Juristische Medien AG 2016.

GÜNTHER, Dirk-Carsten: Der Regreß des Sachversicherers, Kalrsruhe 2008.

KELLER, Alfred: Haftpflicht im Privatrecht, Band I, Sechste, vollständig überarbeitete und ergänzte Auflage, Stämpfli Verlag AG 2002.

KILIÇOĞLU, Ahmet M.: Borçlar Hukuku, Genel Hükümler, Ankara 2018. 
KLETT, Barbara/MÜLLER, Dominique: Risikosteuerung im Umgang mit "Emerging Risk", Editörler: BÜTLER, Micheal/SCHINDLER, Benjamin/SPRECHER, Franziska/ SUTTER Patrick, Sicherheit \&Recht 1/2017- S. 49, s. 49-57, https://www.swisslex.ch/Doc/ShowDocView/8c249f52-26b4-4e5f-b0d690b11f48504f?hitPos=2\&tryHighlight=True\&source=hitlist-search\&SP=12 |dhtpnn\#firstSearchTerm (erişim tarihi: 18.10.2018).

KRATZ, Brigitta/ LUDIN, Martin: Haftpflichtkommentar, Kommentar zu den schweizerischen Haftpflichtbestimmungen, (Herausgeber: FISCHER, Willi / LUTERBACHER, Thierry), Dike Verlag AG, 2016.

MÜLLER, Christof: Obligationenrecht - Allgemeine Bestimmungen Art. 1-183 OR, CHK - Handkommentar zum Schweizer Privatrecht, (Herausgeber: Furrer, Andreas / Schnyder, Anton K.), Schulthess Juristische Medien AG 2016.

NOMER, Halûk: Borçlar Hukuku Genel Hükümler, İstanbul 2017.

OFTINGER, Karl/ STARK, Emil W.: Schweizerisches Haftpflichtrecht, Erster Band: Allgemeiner Teil, 5. Auflage, vollständig überarbeitet und ergänzt von Emil W. StarkANNÉE1995

OĞUZMAN, M. Kemal/ÖZ, M. Turgut: Borçlar Hukuku Genel Hükümler, C. II, İstanbul 2017.

ÖZTAŞ, Illker: 6098 sayılı Türk Borçlar Kanunu Açısından Yapı Malikinin Sorumluluğu, Cevdet Yavuz Anısına Armağan, 6098 Sayılı Türk Borçlar Kanunu Hükümlerinin Değerlendirilmesi Sempozyumu (3 - 4 Haziran 2011), Sempozyum Yayınları 2011, s. 189-204.

PICHONNAZ, Pascal/WERRO, Franz: La responnsabilité fondée sur le risque: un état des lieux et quelques perspectives d'avenir, (édité par WERRO, Franz/PICHONNAZ, Pascal) Colloque du droit de la responsabilité civile 2017, Université de Fribourg, Stämpfli Verlag AG 2018.

SELLA, Mauro: Commentario al Codice Civile, a cura di CENDON Paulo, artt. 20432053, Giuffré Editore 2008 [Cendon Comm].

TANDOĞAN, Halûk: Türk Mesuliyet Hukuku Akit Dışı ve Akdi Mesuliyet, Ankara 1961 [Mesuliyet].

TANDOĞAN, Halûk, Tehlike Sorumluluğu Kavramı, Sorumluluk Hukukunda Yeni Gelişmeler Sempozyumu II, İstanbul 1981 [Yeni Gelişmeler].

TEKINAY, Selahattin Sulhi / AKMAN, Sermet / BURCUOĞLU, Haluk/ALTOP, Atilla: Borçlar Hukuku Genel Hükümler, ìstanbul 1993. 
TiFTiK, Mustafa, Türk Hukukunda Tehlike Sorumluluklarının Genel Kural İle Düzenlenmesi, Yetkin Yayınları, Ankara 2005.

TRIMARCHI, Pietro: Istituzioni di Diritto Privato, Giuffré Editore 2011.

ULUSAN, Illhan, Tehlike Sorumluluğu Üstüne, MHAD, Yıl 1970, Cilt 4, Sayı 6, s. 23-57 [Tehlike].

ULUSAN, Illhan: Türk Borçlar Kanununda Yer Alan Genel Tehlike Sorumluluğu Kuralına ilişkin Birkaç Tespit ve Hukuk Düzeni Tarafından Faaliyetine İzin Verilmiş Önemli Ölçüde Tehlike Arzeden İşletmelerin Yol Açtı̆̆ı Zararların Uygun Bir Bedelle Denkleştirilmesi Sorunu, Journal of Yaşar University, Cilt: 8, Özel Sayı, Prof. Dr. Aydın Zevkliler'e Armağan, 2013, s. 2897-2905 [Denkleştirme Sorunu].

WELLER, Matthias: Haftungsrecht Gefahrstoffe: die zivilrechtliche Haftung für Schäden aus gefährlichen chemischen Reaktionen, Ecomed-Storck $\mathrm{GmbH}$, 2007.

WERRO, Franz: La responsabilité civile, Stämpfli Verlag AG 2017 [Responsabilité].

WERRO, Franz: Comentaire Romand, Code des obligations I, Art.1-529, (Edité par THÉVENOZ, Luc/WERRO, Franz), Helbing Lichtenhahn Verlag, Basel 2012 [CR-CO].

YAVUZ, Mustafa: Elektrik Piyasası Kanunu'nun Öngördüğü Hukuki Rejim ve Elektrik Tedarik Sözleşmeleri-Özellikle İkili Anlaşma-, İstanbul 2011. 